Article

\title{
The Influence of Various $N$-Heterocyclic Carbene Ligands on Activity of Nitro-Activated Olefin Metathesis Catalysts
}

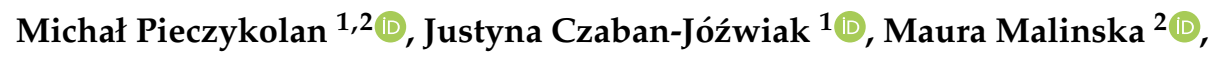 \\ Krzysztof Woźniak ${ }^{2}$ D, Reto Dorta ${ }^{3}$, Anna Rybicka ${ }^{2}$, Anna Kajetanowicz ${ }^{2, * \mathbb{D}}$ \\ and Karol Grela $1,2, *$ \\ 1 Institute of Organic Chemistry Polish Academy of Sciences, Kasprzaka 44/52, 01-224 Warsaw, Poland; \\ michalpieczykolan@gmail.com (M.P.); czaban.justyna@gmail.com (J.C.-J.) \\ 2 Faculty of Chemistry, Biological and Chemical Research Centre, University of Warsaw, Żwirki i Wigury 101, \\ 02-089 Warsaw, Poland; mmalinska@chem.uw.edu.pl (M.M.); kwozniak@chem.uw.edu.pl (K.W.); \\ annamariarybicka@gmail.com (A.R.) \\ 3 Department of Chemistry, School of Molecular Sciences, University of Western Australia, \\ 35 Stirling Highway, Perth 6009, Australia; reto.dorta@uwa.edu.au \\ * Correspondence: a.kajetanowicz@uw.edu.pl (A.K.); prof.grela@gmail.com (K.G.)
}

Academic Editor: Yves Canac

Received: 16 April 2020; Accepted: 8 May 2020; Published: 12 May 2020

\begin{abstract}
A set of nitro-activated ruthenium-based Hoveyda-Grubbs type olefin metathesis catalysts bearing sterically modified N-hetero-cyclic carbene (NHC) ligands have been obtained, characterised and studied in a set of model metathesis reactions. It was found that catalysts bearing standard SIMes and SIPr ligands $(\mathbf{4 a}$ and $\mathbf{4 b}$ ) gave the best results in metathesis of substrates with more accessible $\mathrm{C}-\mathrm{C}$ double bonds. At the same time, catalysts bearing engineered naphthyl-substituted NHC ligands (4d-e) exhibited high activity towards formation of tetrasubstituted C-C double bonds, the reaction which was traditionally Achilles' heel of the nitro-activated Hoveyda-Grubbs catalyst.
\end{abstract}

Keywords: metathesis; ruthenium; nitro catalysts; NHC ligands; olefins

\section{Introduction}

Although first transition metal complexes bearing $\mathrm{N}$-heterocyclic carbene (NHC) ligands were studied independently by Wanzlick [1] and Öfele [2] in the late 1960s, these intriguing species remained unexplored for many years. They re-entered the stage in 1991 when Arduengo and co-workers prepared the first stable and crystalline $N$-heterocyclic carbene (IAd) [3]. Since then, because of easy fine-tuning of the steric and electronic properties of these compounds [4], NHCs have been widely used both as organocatalysts and as ligands for numerous transition metals catalysed reactions [5].

Olefin metathesis is a useful methodology enabling formation of multiple carbon-carbon double bonds [6-8]. Pioneering studies on this reaction were undertaken by scientists working in industry and in academia, where one might mention milestone contributions by Anderson and Merckling (Du Pont-norbornene polymerization) [9], Banks and Bailey (Philips Petroleum-so-called the three-olefin process) [10], and Natta (linear and cyclic olefin polymerization) [11]. In these early contributions, undefined catalytic systems and harsh conditions were usually applied, which limited the applicability of this transformation to rather simple systems. The discovery of Schrock's molybdenum [12] and Grubbs' first-generation ruthenium [13] complexes in the 1990s significantly enhanced pertinence of this methodology, but the real avalanche of olefin metathesis applications happened only after the introduction of the so-called second-generation Ru catalysts, i.e., Ru-complexes bearing at least one NHC ligand [14-16]. Currently, a number of complexes are commercially available, 
inter alia, general-use catalysts like Umicore Grubbs Catalyst M2a (1a) [17] introduced in 1999 [18] and its SIPr variant (1b), Umicore M2 (2a) [19], Hoveyda-Grubbs' catalyst (3a) [20] and SIPr analogue (3b), and nitro-catalysts $\mathbf{4 a}, \mathbf{b}$ (Figure 1) [21-23].

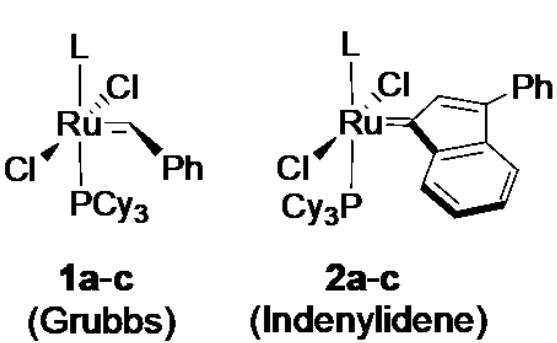<smiles>CC(C)Oc1ccccc1C=[R14](Cl)(Cl)Cl</smiles>

3a,b (Hoveyda-Grubbs)

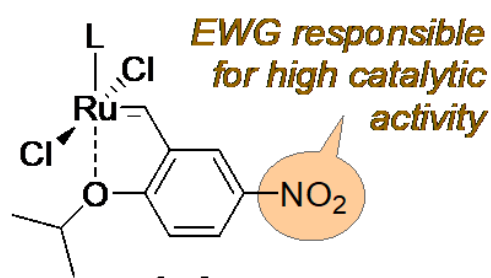

4a,b (Nitro)

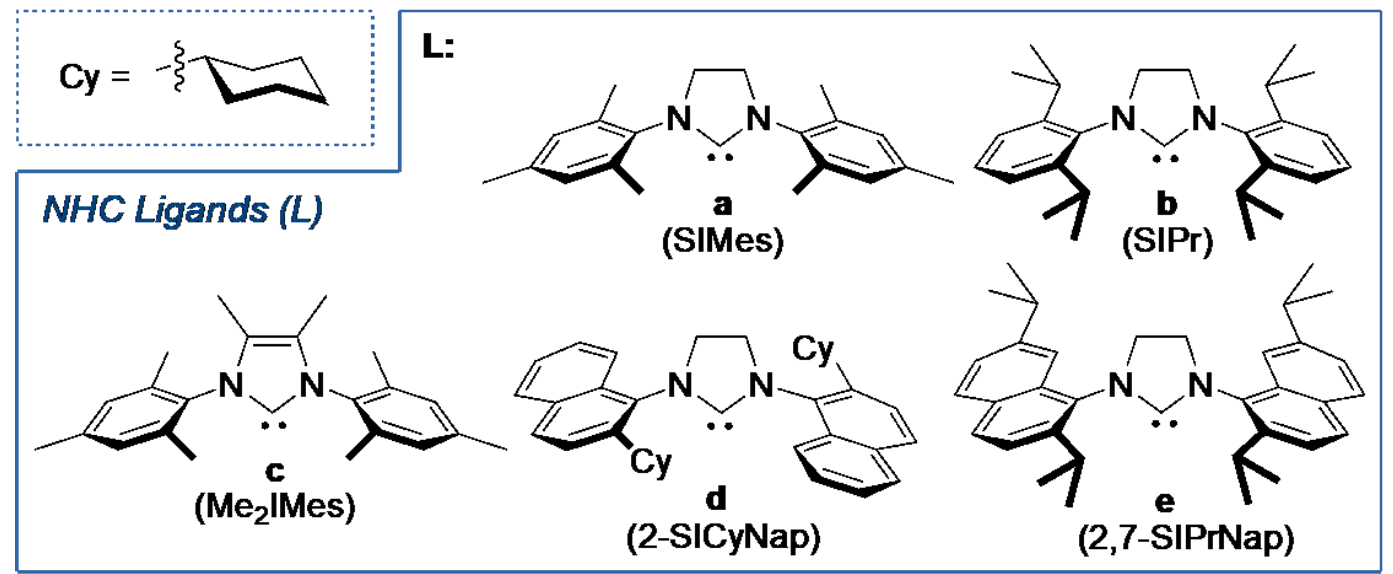

Figure 1. Examples of commercial Ru-based olefin metathesis catalysts and $N$-heterocyclic carbene (NHC) ligands (a-e).

Given the importance of the NHC ligand in ruthenium olefin metathesis catalysts, these ligands (L) have been optimised over the years. It was found that modification of the central five-membered $N$-heterocycle leads to decreasing activity or faster decomposition of the corresponding complex [24,25]. Similar results were obtained when replacing the aromatic side chain substituents with aliphatic ones [26-30]. However, unsymmetrically substituted NHC ligands, bearing one aromatic and one aliphatic $N$-substituent, have found their important niche as specialised catalysts [31-33]. On the other hand, introducing slightly bulkier aryl substituents compared to SIMes [34-37] or modifications of the 4 and 5 position in the imidazolium ring [26,38-40] cause usually an opposite effect resulting in an increase of the catalysts' activity.

Besides varying the NHC ligand, benzylidene ligands offer a broad testing ground for modifications of the catalytic properties of these ruthenium complexes [41]. Our group has developed a nitro-activated version of the Hoveyda complex 4a [42-45]. The presence of an electron-withdrawing group (EWG) $[43,46]$ in para position results in weakening of Ru-O bond, therefore accelerating the initiation rate of the resulting catalyst. As a consequence, $\mathbf{4} \mathbf{a}$ has been utilised as a successful metathesis catalyst in natural products and target-oriented syntheses $[47,48]$, as well as the industrial context, such as in the ring-closing metathesis (RCM) at scale up to $7 \mathrm{~kg}$ leading to the antiviral BILN 2061 agent precursor at Boehringer-Ingelheim plant $[49,50]$, anticancer agent Largazole at decagrams scale at Oceanyx Pharmaceuticals, Inc. [51], and in continuous flow using a scalable membrane pervaporation device at Snapdragon Chemistry, Inc. [52]. Interestingly, the iodide-containing analogue of 4 a gave very good results in a number of challenging CM and RCM reactions [53]. Importantly, increased stability towards ethylene makes this diiodo derivative especially suitable for macrocyclization RCM of unbiased dienes [53]. Based on the excellent results reported by Bertrand and Grubbs on cyclic-alkyl-amino carbene (CAAC) ligands [54], Skowerski et al. obtained a CAAC analogue of 4a that promoted 
difficult RCM macrocyclization at $30 \mathrm{ppm}$, and cross metathesis of acrylonitrile at $300 \mathrm{ppm} \mathrm{Ru}$ loading and lower [55]. In addition, the successful nitro-catalyst design has provided an impetus for developing a number of derivative catalysts utilising the same EWG-activation concept [46,56-58]. On the other hand, replacement of the chelating oxygen atom by groups containing sulphur [59-61] or nitrogen [61-63] results in so-called latent complexes [64,65]. These catalysts exhibit increased stability, but have to be activated thermally, chemically or photochemically.

Herein, we describe the synthesis of a small set of nitro-activated catalysts bearing NHC ligands (L) of different steric properties (Figure 1 and Scheme 1). Catalyst 4a bearing a well-known SIMes ligand (Figure 1, NHC structures: a) was chosen as the benchmark, while the less known SIPr (Figure 1, 4b) [53] and the new complexes with $\mathrm{Me}_{2} \mathrm{IMes}$ [40] and with two naphthalene based ligands (Figure 1, NHC structures: c-e) developed by Dorta, were studied in detail [66-69]. These five complexes were characterised structurally and then tested in model olefin metathesis reactions [70] to check how steric properties of the different NHC ligands influence structural and catalytic properties of the resulting Ru complexes.

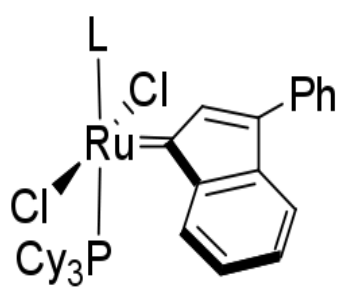

2a-b

$a(L=S I M e s)$

b $(L=S I P r)$<smiles>Cl[R](Cl)(Cl)C=[Pb]</smiles>

1c-e

c $\left(\mathrm{L}=\mathrm{Me}_{2} \mid \mathrm{Mes}\right)$

d $(\mathrm{L}=2$-SICyNap) e $(L=2,7-S I P r N a p)$

$\mathrm{CuCl}$
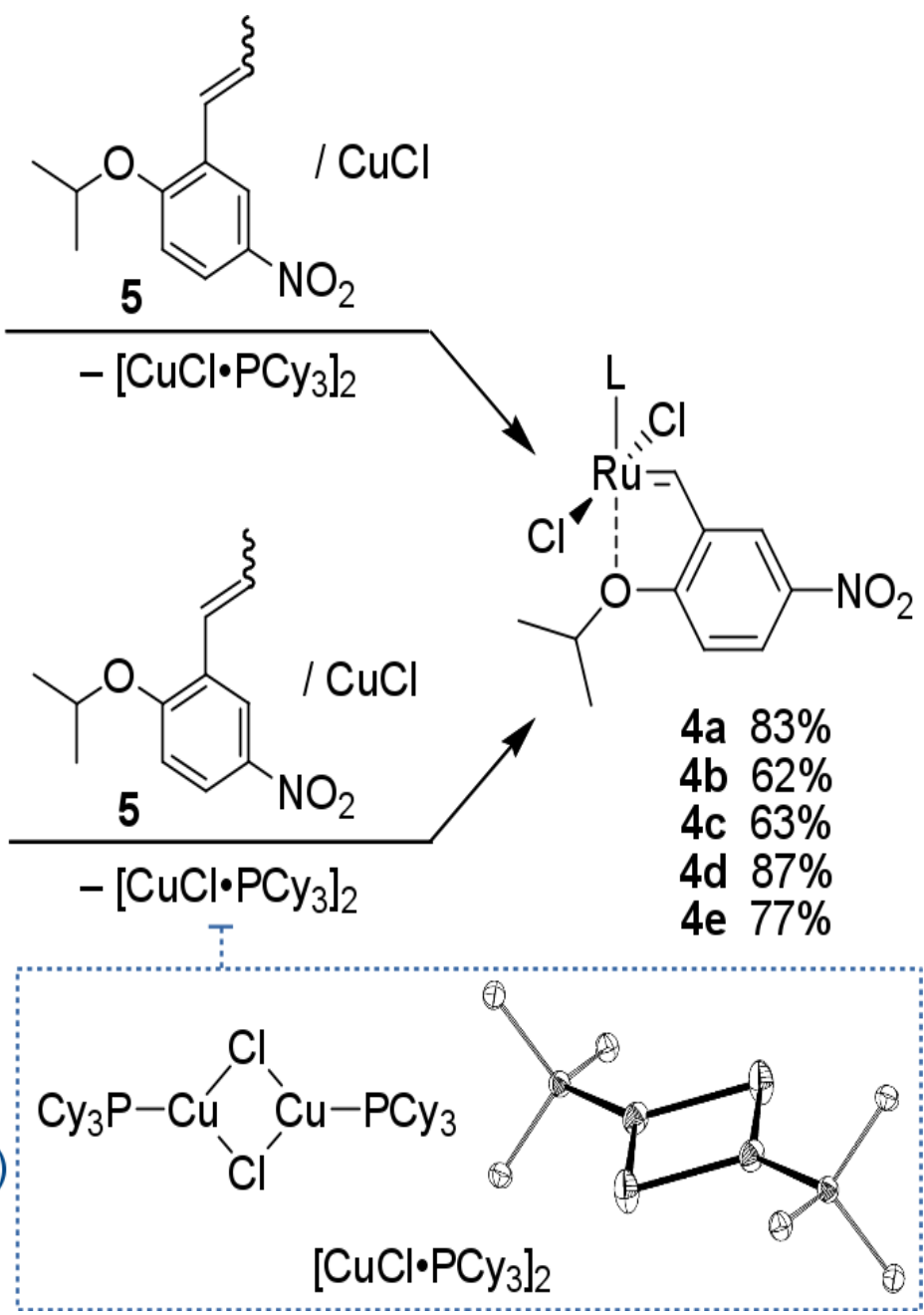

Scheme 1. Synthesis of complexes $4 \mathbf{a}-\mathbf{e}$.

\section{Results and Discussion}

\subsection{Synthesis of the Ruthenium Complexes}

All complexes were synthesised via the stoichiometric metathesis-ligand exchange reaction according to a procedure initially disclosed by Hoveyda [71] and illustrated on Scheme 1. Depending on 
the NHC precursor, the reactions were performed either in toluene or in DCM, in the presence of copper(I) chloride- a commonly used phosphine scavenger [71]. Complexes $4 \mathbf{a}$ and $\mathbf{4 b}$ were obtained from commercially available second-generation indenylidene complexes $\mathbf{2 a}$ and $\mathbf{2 b}$ in $83 \%$ and $62 \%$ yield, respectively. Interestingly, during these syntheses, we were able to isolate the putative $\mathrm{CuCl} \bullet \mathrm{PCy}_{3}$ complex in pure form and solve its crystallographic structure. It is stated that despite the fact that $\mathrm{CuCl}$ is being used as a phosphine scavenger in the preparation of various Hoveyda complexes for almost 20 years [71], according to our knowledge the product of this reaction has not yet been unambiguously characterised [72]. The synthesis of complexes $\mathbf{4} \mathbf{c}-\mathbf{e}$ was carried out using appropriate Grubbs second generation complexes $\mathbf{1} \mathbf{c}-\mathbf{e}$ as the source of ruthenium $[40,66,68,73]$.

Complex $4 \mathrm{c}$ was obtained in the reaction of $1 \mathrm{c}$ with propenylbenzene derivative 5 in the presence of $\mathrm{CuCl}$ as a microcrystalline brownish solid with a moderate yield of $63 \%$. Complexes $4 \mathrm{~d}$ and $4 \mathrm{e}$ were obtained in a similar way from 5 and corresponding Grubbs-type catalysts $[66,68,73] \mathbf{1 d}$ or $\mathbf{1 e}$ as greenish microcrystalline solids in good yields, $87 \%$ and $77 \%$ respectively. General conditions for the synthesis of complexes $\mathbf{4 a - e}$ are shown in Table 1. As solids, all new Ru-compounds were stable when under an inert atmosphere and were stored for weeks without any sign of decomposition (acc. to TLC and NMR). Having these catalysts in hand, we were ready to study how different NHC arrangements [74] present in $\mathbf{4 a - e}$ influence the resulted complex structures and activity.

Table 1. Detailed conditions used in synthesis of $4 \mathbf{a}-\mathbf{e}$.

\begin{tabular}{ccccc}
\hline Catalyst & Solvent & Time $(\mathbf{m i n})$ & Temp. $\left({ }^{\circ} \mathbf{C}\right)$ & Yield $(\%)$ \\
\hline 4a & Toluene & 60 & 80 & 83 \\
4b & Toluene & 60 & 80 & 60 \\
4c & Toluene & 60 & 60 & 63 \\
4d & DCM & 20 & 40 & 87 \\
4e & DCM & 10 & 40 & 77 \\
\hline
\end{tabular}

\subsection{Structure Analysis}

The crystal structures of $\mathbf{4 b} \mathbf{b}-\mathbf{e}$ have been determined by applying single crystal X-ray diffraction (Figure 2). It allows for investigation of structural conformations and steric subtleties of the studied compounds. The structure of $4 \mathbf{a}$ has been previously reported [75] and another related molecule-a catalyst $\mathbf{4 f}$ (Figure 3) developed by Buchmeiser [24] that contains saturated 1,3-bis(2,4,6-trimethylphenyl) 3,4,5,6-tetrahydropyrimidin-2-ylidene ligand-was included in Table 2 for comparison purposes [24] (while selected bond lengths and angles are given in Table 2, the full set of X-ray data is provided in Table S1 in Supplementary Materials).

All ruthenium complexes adopt a distorted square bi-pyramid coordination mode around the central ruthenium atom. The top of these pyramids are the $\mathrm{O}(1)$ oxygen of the benzylidene chelate and the $\mathrm{C}(1)$ carbon atoms of the NHC ligand. The average distance for the $\mathrm{Ru}-\mathrm{Cl}$ bond amounts to $2.33 \AA$ with a small variation from this value and the chloride atoms are in the trans configuration.

Most of the geometrical parameters do not differ much as they stay in the range of the $3 \sigma$ threshold, however some interesting trends can be observed. The substitution of various NHC ligands strongly influences the Ru-O(1) bond. The bond is shortened in comparison to the parent SIMes-bearing (4a) compound (2.287(1) $\AA$ ) with the exception of the NHC ring modification to the 6-member one in the $\mathbf{4 f}$ moiety $(2.310(2) \AA)$.

An opposite trend was found for the Ru-C(1) bond, which is elongated except for the $4 \mathbf{d}$ molecule. The Ru-C(2) bond changes within a smaller range with the shortest distance for the $4 \mathbf{a}$ and $4 \mathbf{c}(1.825(2) \AA$ and 1.821(3) $\AA$, respectively), whereas the longest bond distance is recorded for the 4e structure 1.836(9) $\AA$ and 1.838(9) $\AA$ ). 


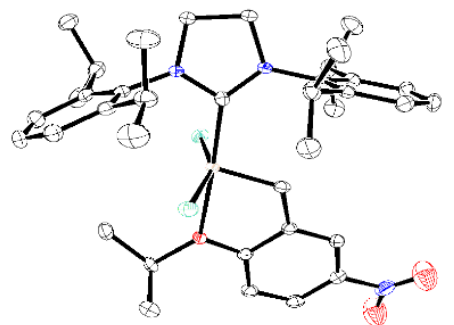

$4 b$

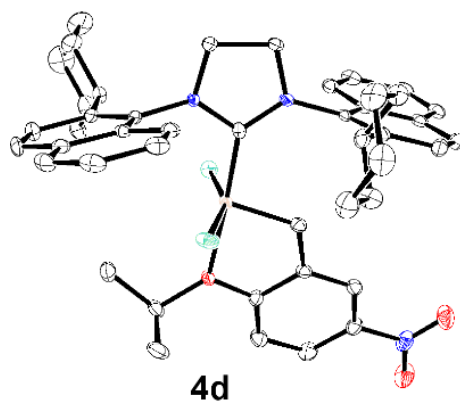

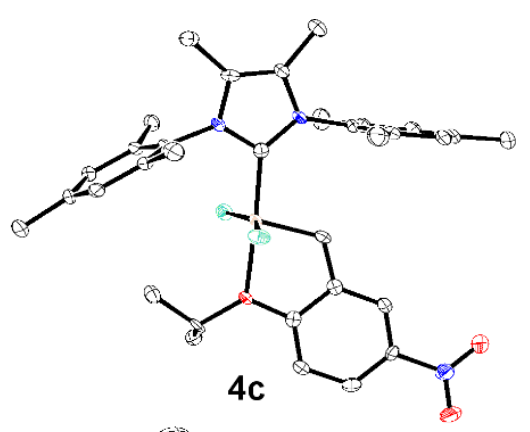

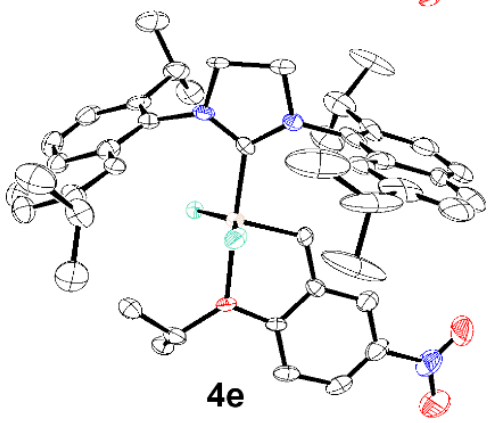

Figure 2. Solid state crystallographic structures of $\mathbf{4 a}, \mathbf{4 b}, \mathbf{4} \mathbf{c}$ and $4 \mathbf{e}$ complexes. Colour codes: blue-nitrogen, red-oxygen, green—chlorine.
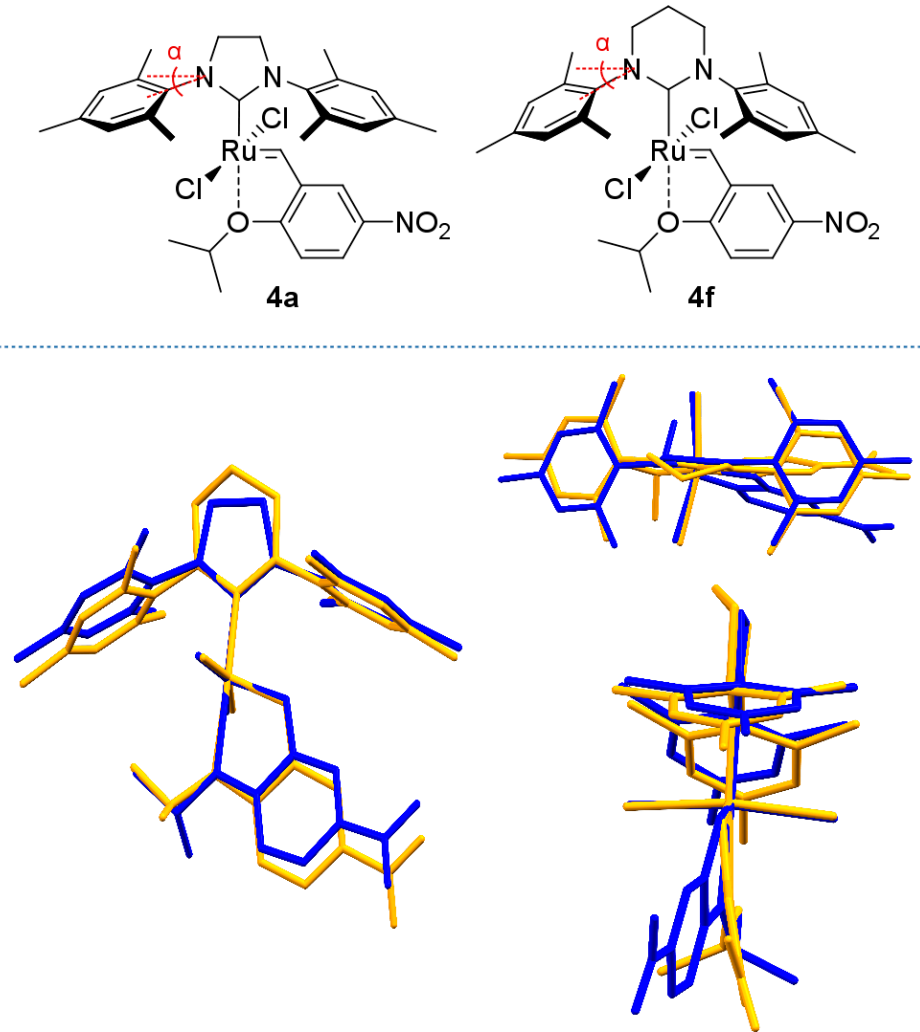

Figure 3. Molecular structures of $4 \mathbf{a}$ and $4 \mathrm{f}$. Front, top, and side view of molecule overlay of $4 \mathbf{a}$ (blue), 4f (orange). For angle $\alpha$ values see Table 2. 
Table 2. Selected bond lengths (Å) and angles (deg) in complexes $4 \mathbf{a}-\mathbf{e}$. The $4 \mathbf{e}$ structure contains two molecules in the asymmetric unit.

\begin{tabular}{ccccccc}
\hline & $\mathbf{4 a}[75]$ & $\mathbf{4 b}$ & $\mathbf{4 c}$ & $\mathbf{4 d}$ & $\mathbf{4} \mathbf{e}^{\mathbf{a}}$ & $\mathbf{4 f}[24]$ \\
\hline $\mathrm{Ru}-\mathrm{C}(1)$ & $1.979(3)$ & $1.985(4)$ & $1.990(4)$ & $1.970(3)$ & $\begin{array}{c}2.002(9) \\
2.012(9)\end{array}$ & $2.013(2)$ \\
\hline $\mathrm{Ru}-\mathrm{O}(1)$ & $2.287(1)$ & $2.244(2)$ & $2.232(2)$ & $2.254(2)$ & $\begin{array}{c}2.285(5) \\
2.252(5)\end{array}$ & $2.310(2)$ \\
\hline $\mathrm{Ru}-\mathrm{C}(2)$ & $1.825(2)$ & $1.829(4)$ & $1.821(3)$ & $1.827(3)$ & $\begin{array}{c}1.836(9) \\
1.838(9)\end{array}$ & $1.825(3)$ \\
\hline $\mathrm{Ru}-\mathrm{Cl}(1)$ & $2.333(1)$ & $2.324(1)$ & $2.335(1)$ & $2.328(1)$ & $\begin{array}{c}2.328(2) \\
2.328(2)\end{array}$ & $2.343(1)$ \\
\hline $\mathrm{Ru}-\mathrm{Cl}(2)$ & $2.330(1)$ & $2.333(1)$ & $2.339(1)$ & $2.331(1)$ & $\begin{array}{c}2.328(2) \\
2.324(2)\end{array}$ & $2.343(1)$ \\
\hline $\mathrm{C}(1)-\mathrm{Ru}-\mathrm{O}(1)$ & $178.45(6)$ & $172.5(1)$ & $175.6(1)$ & $175.4(1)$ & $\begin{array}{c}176.8(3) \\
177.8(3)\end{array}$ & $175.93(8)$ \\
\hline $\mathrm{C}(1)-\mathrm{Ru}-\mathrm{C}(2)$ & $101.36(8)$ & $102.1(1)$ & $103.0(1)$ & $102.4(1)$ & $\begin{array}{c}99.9(4) \\
101.6(4)\end{array}$ & $105.1(1)$ \\
\hline $\mathrm{Ru}-\mathrm{C}(2)-\mathrm{C}(3)-\mathrm{C}(4)$ & $8.6(2)$ & $-8.9(5)$ & $5.9(4)$ & $-5.4(3)$ & $\begin{array}{c}-2(1) \\
2(1)\end{array}$ & $-4.5(3)$ \\
\hline $\mathrm{C}(2)-\mathrm{Ru}-\mathrm{C}(1)-\mathrm{N}(1)$ & $7.6(2)$ & $14.2(4)$ & $5.5(4)$ & $13.0(3)$ & $\begin{array}{c}-31.8(9) \\
27(1)\end{array}$ & $0.8(2)$ \\
\hline$\alpha$ & $19.8(1)$ & $20.8(3)$ & $20.1(2)$ & $19.0(2)$ & $\begin{array}{c}19.4(7) \\
12.4(7)\end{array}$ & $25.4(2)$ \\
\hline $\mathrm{V}$ Bur $(\%)$ & 35.4 & 36.5 & 34.7 & 34.6 & $\begin{array}{c}34.8 \\
36.1\end{array}$ & 38.0 \\
\hline
\end{tabular}

${ }^{a}$ The $4 \mathbf{e}$ structure contains two molecules in the asymmetric unit.

The torsion angles are the most sensitive parameters in the crystal studies, and they differ in all studied complexes, although not that significantly. The Ru-C(2)-C(3)-C(4)-O(1) ring in the Hoveyda pre-catalyst is almost planar. The Ru-C(2)-C(3)-C(4) torsion angle, which defines the mutual orientation of the carbene bond and the NHC ligand is more flexible (Figure 4). Yet again, similar values were found for complexes $\mathbf{4 a}$ and $\mathbf{4} \mathbf{c}$ that form negative torsion angles, whereas one can see positive values of this angle for the $4 \mathrm{~b}$ and $4 \mathrm{~d}$ complexes, with the $4 \mathrm{e}$ precatalyst in the middle of the range. The ligands with more bulky character demand a bigger rotation of the $\mathrm{C}(2)-\mathrm{Ru}-\mathrm{C}(1)-\mathrm{N}(1)$ torsion angle $(\mathbf{4 b}, \mathbf{4} \mathbf{d}$ and $\mathbf{4 e})$.

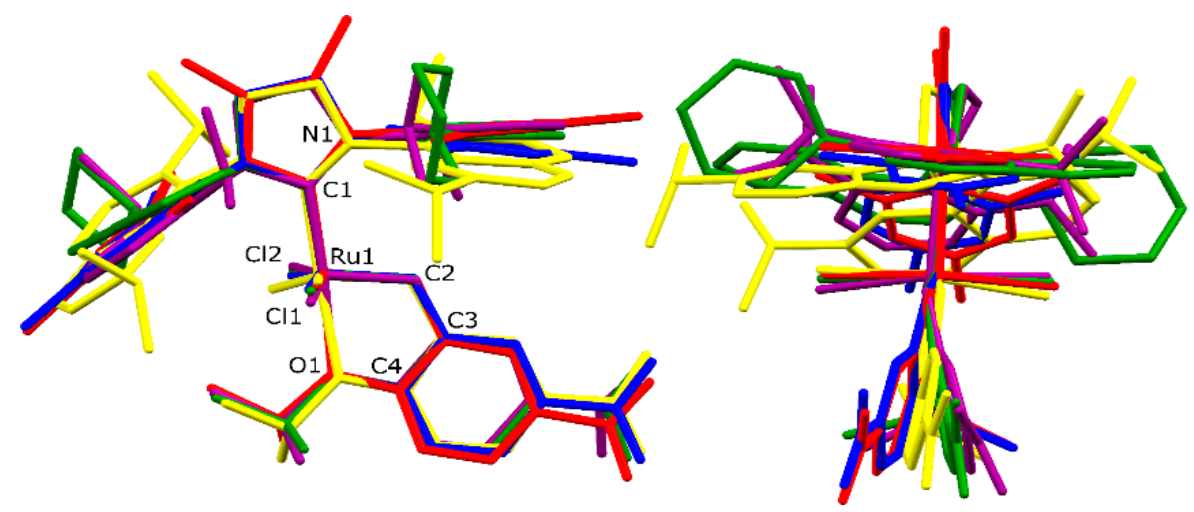

Figure 4. Front and side view of molecule overlay of $4 a$ (blue), $4 b$ (purple), $4 c$ (red), $4 d$ (green) and $4 e$ (yellow) complexes with label used to define selected geometrical parameters.

The angle $\alpha$ (Figure 3 ) represents visually how much the $\mathrm{N}$-aryl 'wings' of the NHC ligands are lowered towards the metal centre. For (S)IMes-decorated complexes $(\mathbf{4 a}, \mathbf{4 c})$ this angle measures 19.8 and $20.1^{\circ}$, and is only slightly larger $\left(20.8^{\circ}\right)$ in the case of SIPr bearing $4 \mathbf{b}$. Importantly, the naphthyl 
members of the series have the $N$-substituents more 'up' $\left(19.0^{\circ}\right.$ for $\left.4 \mathbf{d}\right)$, being in strong contrast to complex $4 \mathrm{f}$ where the NHC wings are visibly lowered $\left(25.4^{\circ}\right)$ thus shielding the $\mathrm{Ru}$ centre more. However, some individual geometrical parameters can mislead the overall comparison. The root means square (RMS) analysis, taking into account the following six atoms: $\mathrm{Ru}, \mathrm{C}(1), \mathrm{C}(2), \mathrm{O}(1), \mathrm{Cl}(1)$ and $\mathrm{Cl}(2)$, has revealed similarity of the studied structures to the initial 4 a compound. The RMS

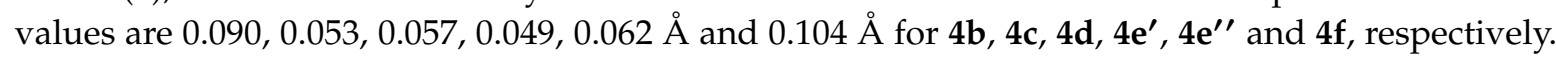
The structures $\mathbf{4 c}, \mathbf{4} \mathbf{d}$ and $4 \mathbf{e}^{\prime}$ revealed a bigger similarity to the $4 \mathbf{a}$ complex, and this finding agrees with the $\mathrm{V}_{\text {bur\% }}$ values.

Using the data obtained from diffraction studies, we also calculated the buried volume $\left(\mathrm{V}_{\text {bur }}\right)$ parameters [76] for the studied series of nitro-catalysts bearing NHC ligands (Figure 5). As expected, $\mathrm{V}_{\text {bur\% }}$ value of SIPr in $\mathbf{4 b}(36.5 \%)$ was bigger than the one of SIMes in $4 \mathbf{a}(35.4 \%)$ and $\mathrm{Me}_{2} \mathrm{IMes}_{\text {in }} 4 \mathrm{c}$ $(34.7 \%)$. The value obtained for Dorta's 2-SICyNap, present in catalyst $4 \mathbf{d}(34.6 \%)$ was similar to the one obtained for $\mathrm{Me}_{2} \mathrm{IMes}$ in $4 \mathrm{c}(34.7 \%)$, even though the (cyclohexyl)naphthyl groups in $4 \mathbf{d}$ can be considered as relatively bulkier in comparison with smaller Mes $N$-substituents in 4c. Therefore it seems that they have similar steric demand of ligand (at least in the proximity of $\mathrm{Ru}$ ).

Because crystals of catalyst $4 \mathbf{e}$ that were measured by us contained two molecules in the asymmetric unit $\left(4 \mathbf{e}^{\prime}\right.$ and $\left.4 \mathbf{e}^{\prime \prime}\right)$, the $V_{\text {bur\% }}$ values were calculated for each of them (Table 2$)$. The relatively big difference between them was probably caused by various spatial arrangements of the naphthyl groups in both of these molecules. $4 \mathbf{a}$ and $\mathbf{4 c}$ had the smallest $\mathrm{NHC}$, while the $\mathbf{4 d}$ and $4 \mathrm{e}^{\prime \prime}$ the largest. In the case of compounds $4 b$ and $4 e^{\prime \prime}$ the greater steric hindrance around the $R u$ atom is visible on the $V_{\text {bur }}$ maps, which directly influenced the increased calculated $V_{\text {bur }}$ value. The least protected Ru centre in this series is visible for complexes $\mathbf{4} \mathbf{c}$ and $\mathbf{4 d}$ and corresponds to the lowest $\mathrm{V}_{\text {bur }}$ values. Buchmeiser's catalyst $\mathbf{4 f}$ has the highest $\mathrm{V}_{\text {bur }}$ value, which is probably correlated to the presence of the pyrimidine ring and different electron density than for the other NHCs. The difference between $\mathbf{4 f}$ and other catalysts is marginal and is best visible for $10 \AA$ radii (Figure $5 \mathrm{f}$ ), where below the central atom some negative electron density is visible. 

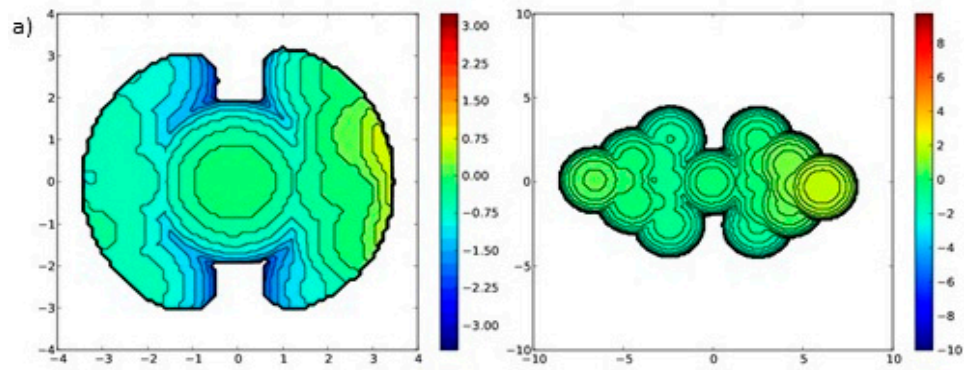

b)
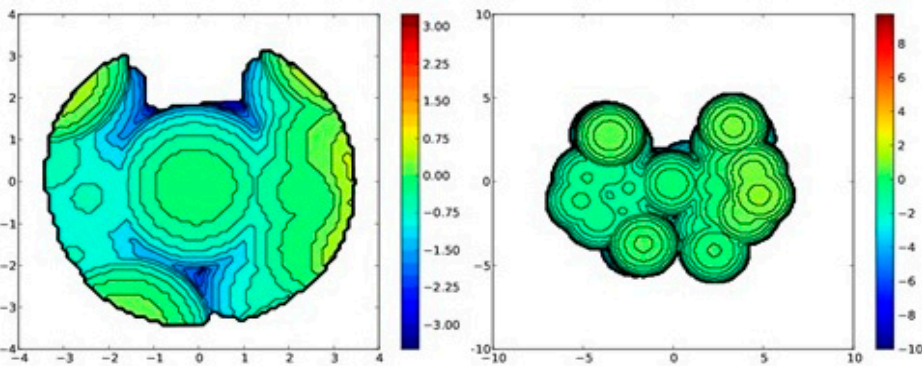

c)
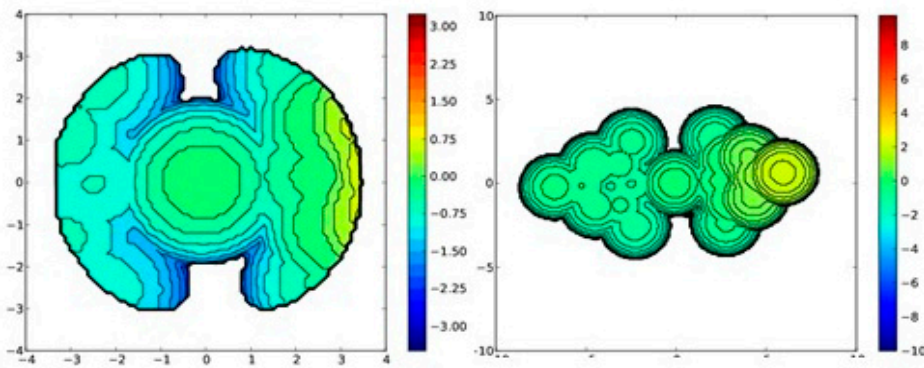

d)
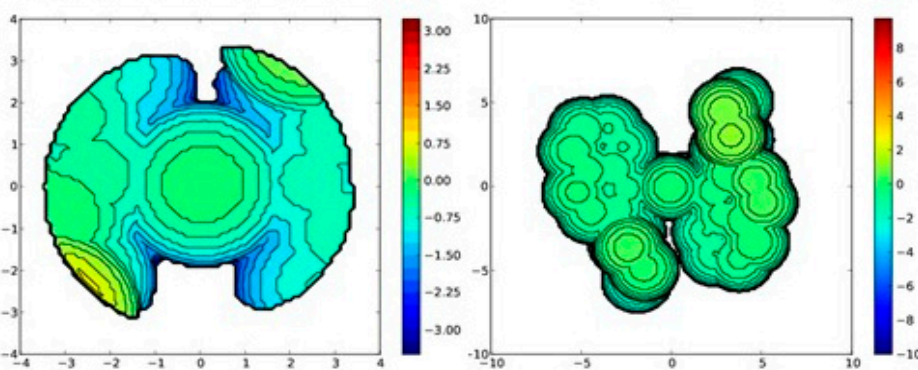

e)
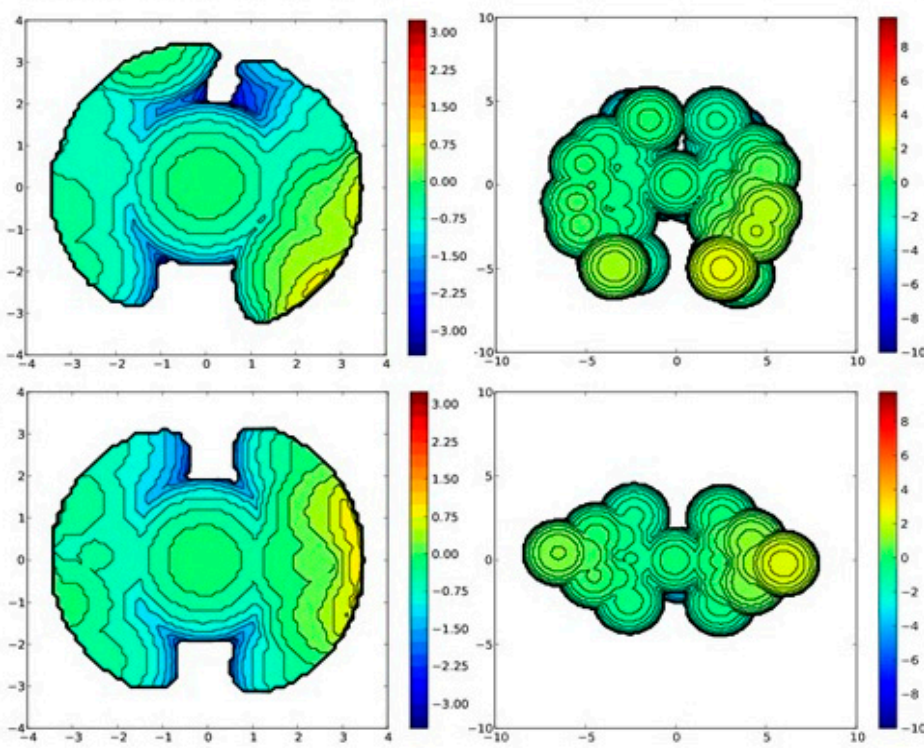

Figure 5. Steric maps calculated in SambVca software for complexes $4 \mathbf{a}$ to 4 f. Standard ( $3.5 \AA)$ and

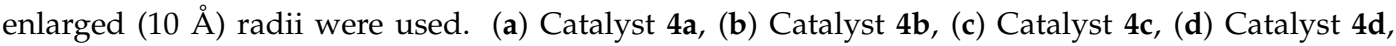
(e) Catalyst 4e, (f) Catalyst $4 \mathrm{f}$. 


\subsection{Comparative Catalytic Activity Studies of Nitro-Catalysts $4 a-e$}

The performance of the nitro-catalysts $4 \mathbf{a}-\mathbf{e}$ was evaluated in the ring-closing and ene-yne metathesis of six model substrates: diethyl 2,2-diallylmalonate (6), diethyl 2-allyl-2-(2-methylallyl)malonate (8), 2,2-di(2-methylallyl)tosylate (10), diethyl 2,2-di(2-methylallyl)malonate (12), allyl 1,1-diphenylpropargyl ether (14), and (1-(prop-1-en-2-yl-methoxy)prop-2-yne-1,1-diyl)dibenzene (16). In the first stage of this research the RCM reaction of 2,2-diallylmalonate (6), the most commonly used model substrate [77] was examined in the presence of $1 \mathrm{~mol} \%$ of nitro-catalysts $4 \mathbf{a}-\mathbf{e}$ (Scheme 2). Reactions were performed in NMR tubes at ambient temperature.

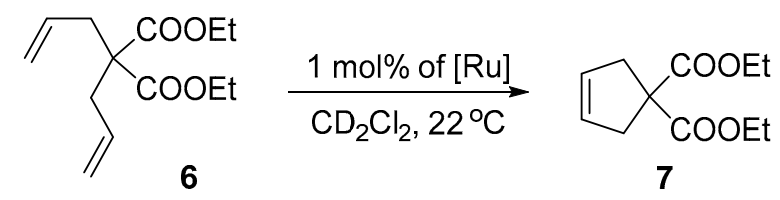

Scheme 2. Ring-closing metathesis (RCM) of diethyl 2,2-diallylmalonate (6).

As expected for the EWG-activated family of catalysts, all tested complexes showed high activity and almost quantitative conversion was achieved after only 10-15 min (Figure 6).

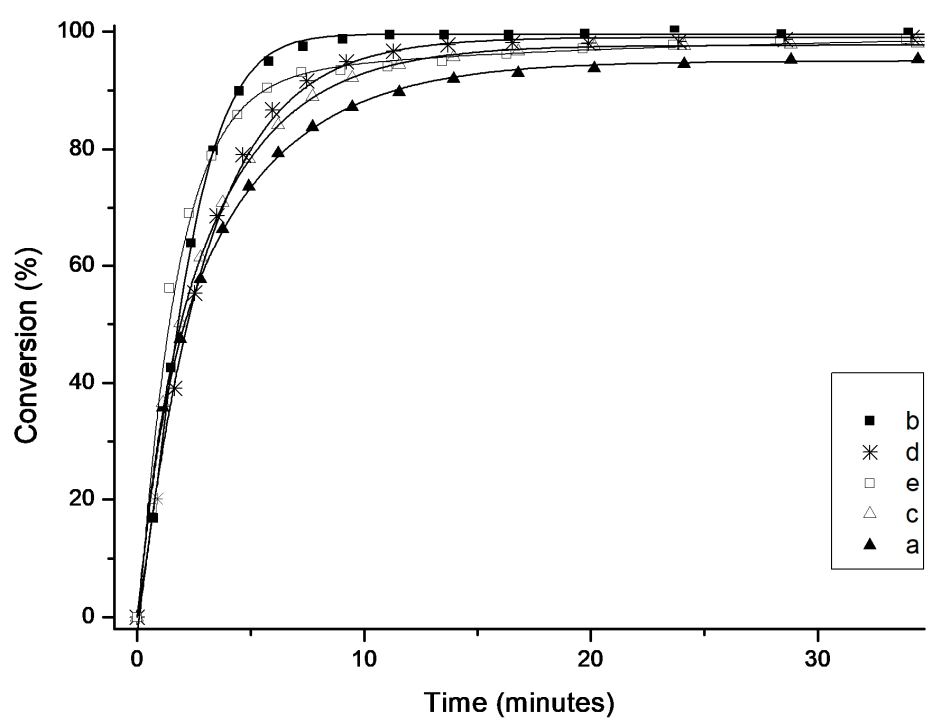

Figure 6. Time/conversion curves for the RCM reaction of diethyl 2,2-diallylmalonate (6) with $1 \mathrm{~mol} \%$ of $4 \mathbf{a}-\mathbf{e}$ at $23{ }^{\circ} \mathrm{C}$ (monitored by $\left.{ }^{1} \mathrm{H}-\mathrm{NMR}\right)$. Lines are visual aids only.

Interestingly, the least active complex was the SIMes-containing 4a. Complex $4 \mathbf{c}$ with an unsaturated $\mathrm{Me}_{2} \mathrm{IMes}$ ligand initiated slightly faster and provided maximal conversion after approximately 15 minutes. Both catalysts containing naphthyl substituents in their NHC ligands $4 \mathbf{d}$ and $4 \mathbf{e}$ exhibited even higher activity, with a slightly better result obtained for cyclohexyl-substituted catalyst $\mathbf{4 d}$. The most active complex in the series was $\mathbf{4 b}$ bearing the SIPr ligand, which gave full conversion in less than $10 \mathrm{~min}$.

Diethyl 2,2-diallylmalonate (6) is a rather simple substrate to ring-close and is used more to examine whether a newly obtained complex exhibits any catalytic metathesis activity than to show in detail the subtle differences between similarly active catalysts. To determine how the activity of the new Ru-complexes compare, a more difficult substrate containing substituted double bonds, diethyl 2-allyl-2-(2-methyllyl)malonate (8) was studied next (Scheme 3, Figure 7). 


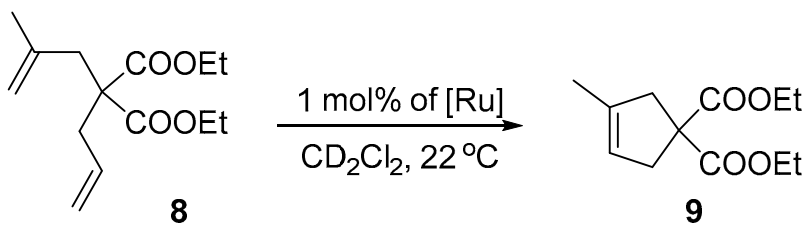

Scheme 3. RCM reaction of diethyl 2-allyl-2-(2-methylallyl)malonate (8).

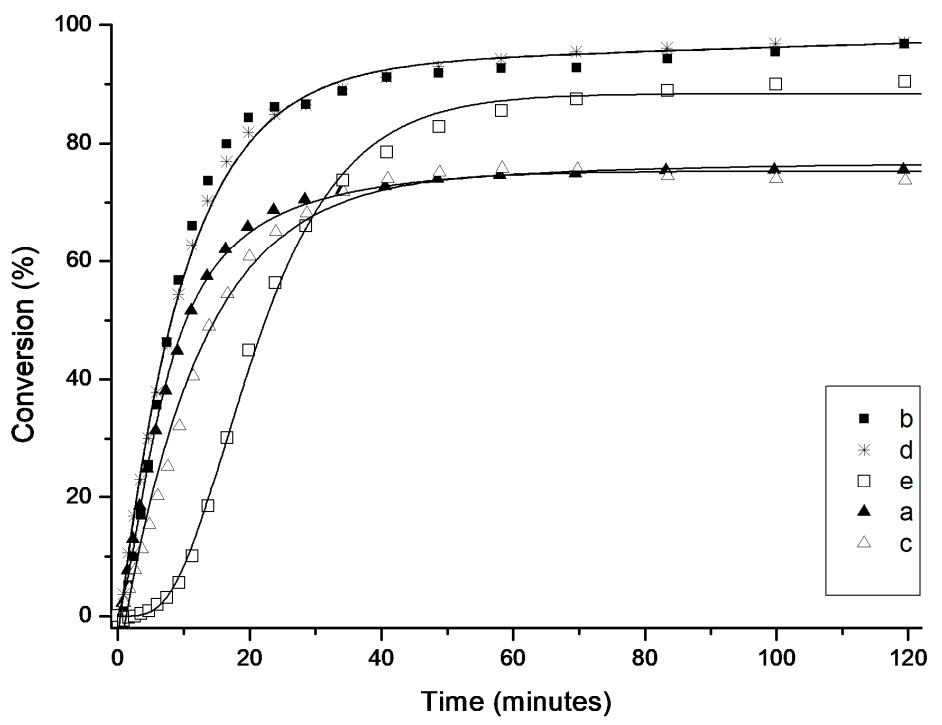

Figure 7. Time/conversion curves for the RCM reaction of diethyl 2-allyl-2-(2-methylallyl)malonate (8) with $1 \mathrm{~mol} \%$ of $4 \mathbf{a}-\mathbf{e}$ at $23{ }^{\circ} \mathrm{C}$ (monitored by $\left.{ }^{1} \mathrm{H}-\mathrm{NMR}\right)$. Lines are visual aids only.

In this case, under similarly mild conditions as used for the RCM of 6, namely in the presence of $1 \mathrm{~mol} \%$ catalyst and at room temperature, the general trend was maintained, although higher diversity between the tested catalysts was found (Figure 7). The highest activity was observed for $\mathbf{4 b}$ (SIPr) and 4d, (2-SICyNap) complexes containing relatively large aryl substituents in the NHC ligand. After 20 minutes they reached 84 and $81 \%$ yield, respectively, reaching in both cases $97 \%$ of RCM product 9 within $2 \mathrm{~h}$.

An interesting S-shaped curve was observed for the second complex bearing bulky naphthyl-substituted NHC (4e). The latter admittedly initialised slower than the other counterparts, as after $20 \mathrm{~min}$ it reached only $45 \%$ conversion. Interestingly, after this initial latency period $4 \mathbf{e}$ initiated in a fast rate giving after $100 \mathrm{~min} 90 \%$ conversion of 8 . As observed previously for the conversion of 6 to 7 , the least reactive complexes in this model reaction were $4 \mathbf{a}$ and $\mathbf{4 c}$, which initiated quicker than $4 \mathbf{e}$ but after two hours provided the product with only 75 and $73 \%$ yield, respectively.

Next, we examined the activity of the nitro-catalysts in the RCM formation of tetrasubstituted olefins. Dienes 2,2-di(2-methyl allyl)tosylate (10) and diethyl 2,2-di(2-methyl allyl)malonate (12) are known to be more demanding and usually require the use of harsh conditions and specifically designed catalysts in order to achieve high yields [78]. Here, the reactions were performed in the presence of $5 \mathrm{~mol} \%$ of complexes $4 \mathrm{a}-\mathbf{e}$ at $80^{\circ} \mathrm{C}$ (Scheme 4$)$.

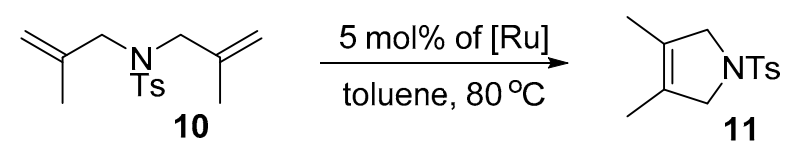

Scheme 4. RCM reaction of 2,2-di(2-methylallyl)tosylate (10). 
When tosylate 10 was used (Scheme 4), good to very good yields were achieved, however a significant difference between complexes bearing bulky naphthyl substituted NHCs (4d and $4 \mathbf{e})$ and the more standard ones $(4 \mathbf{a}-\mathbf{c})$ was observed (Figure 8). Despite the forcing conditions such as high catalyst loading and elevated temperature, the SIMes, SIPr and $\mathrm{Me}_{2} \mathrm{IMes}-$ bearing catalysts produced 10 in 76-83\% yield after one hour. In contrast, bulkier Dorta-type complexes $4 \mathbf{d}$ and $4 \mathbf{e}$ reached almost quantitative conversion, 90 and 91\% respectively, after only $20 \mathrm{~min}$. Interestingly, when the reaction time was extended to $24 \mathrm{~h}$ also complex with SIPr ligand (4b) achieved a similar conversion of $91 \%$, while $4 \mathbf{a}$ and $4 \mathrm{c}$ died reaching $80-82 \%$ only (Table 3 ).

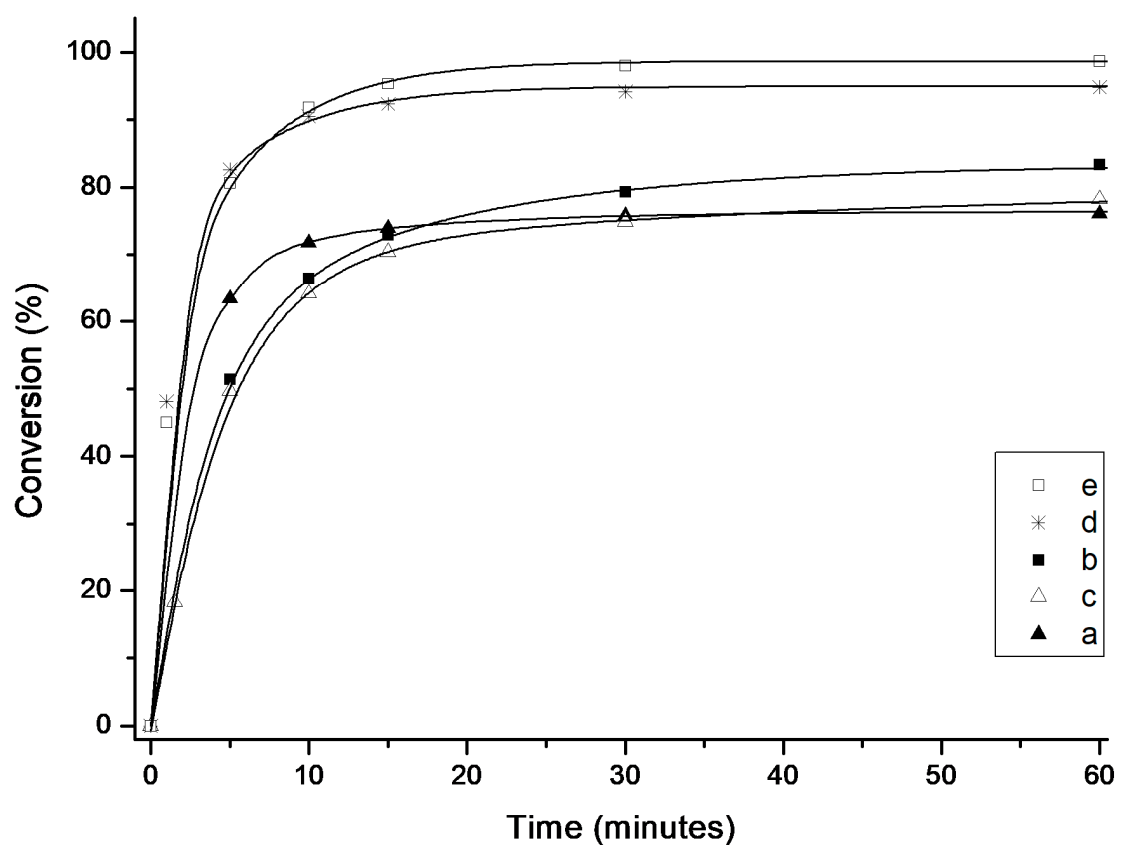

Figure 8. Time/conversion curves for the RCM reaction of 2,2-di(2-methylallyl)tosylate (10) with $5 \mathrm{~mol} \%$ of $4 \mathbf{a}-\mathbf{e}$ at $80^{\circ} \mathrm{C}$ (monitored by GC). Lines are visual aids only.

Table 3. RCM reaction of 2,2-di(2-methylallyl)tosylate (10) with $5 \mathrm{~mol} \%$ of $4 \mathbf{a}-\mathbf{e}$ at $80{ }^{\circ} \mathrm{C}$ (monitored by GC) after 1 and $24 \mathrm{~h}$.

\begin{tabular}{ccc}
\hline \multirow{2}{*}{ Catalyst } & \multicolumn{2}{c}{ Conversion (\%) } \\
\cline { 2 - 3 } & After $\mathbf{1 ~ h}$ & After $\mathbf{~ 4} \mathbf{h}$ \\
\hline $\mathbf{4 a}$ & 76 & 82 \\
$\mathbf{4 b}$ & 83 & 91 \\
$\mathbf{4 c}$ & 78 & 80 \\
$\mathbf{4 d}$ & 98 & 99 \\
$\mathbf{4 e}$ & 95 & 97 \\
\hline
\end{tabular}

When even more challenging diethyl 2,2-di(2-methylallyl)malonate (12) was used instead of 2,2-di(2-methylallyl)tosylate (10) in the presence of $5 \mathrm{~mol} \%$ of $\mathrm{Ru}$ at $80{ }^{\circ} \mathrm{C}$ (Scheme 5 , Table 4 ), only the most bulky Dorta complex 4 e provided a relatively satisfactory result of $62 \%$ yield in $6 \mathrm{~h}$. The other complexes (4a-d) were less active, leading to $9-21 \%$ of the desired product 13. 


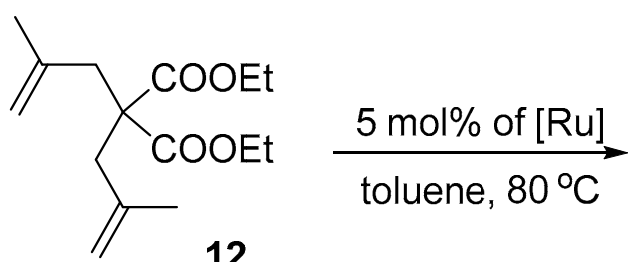

12

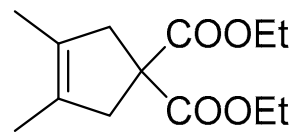

13

Scheme 5. RCM reaction of diethyl 2,2-di(2-methylallyl)malonate (12).

Table 4. RCM reaction of diethyl 2,2-di(2-methylallyl)malonate (12) with $5 \mathrm{~mol} \%$ of 4 a-e at $80{ }^{\circ} \mathrm{C}$ (monitored by GC) after 6 and $24 \mathrm{~h}$.

\begin{tabular}{ccc}
\hline \multirow{2}{*}{ Catalyst } & \multicolumn{2}{c}{ Conversion (\%) } \\
\cline { 2 - 3 } & After $\mathbf{6} \mathbf{~ h}$ & After $\mathbf{2 4} \mathbf{~ h}$ \\
\hline 4a & 16 & 18 \\
$\mathbf{4 b}$ & 9 & 63 \\
4c & 21 & 21 \\
4d & 14 & 66 \\
4e & 62 & 84 \\
\hline
\end{tabular}

After extending the reaction time to $24 \mathrm{~h}$, virtually no changes in conversion were observed in the case of complexes with mesitylene-based NHC ligands (4a and 4c). Pleasurably, we noticed a huge improvement in yield of the desired product when the reaction was conducted in the presence of Dorta-type (4e and $\mathbf{4 d}$ ) and SIPr-based (4b) catalysts (Table 4). Especially in the case of the latter two, changes were significant (from $14 \%$ to $66 \%$ for $4 \mathrm{~d}$ and from $9 \%$ to $63 \%$ for $4 \mathrm{~b}$ ).

Ene-yne metathesis is a highly selective and atom-economical methodology for the synthesis of 1,3 dienes, which are valuable building blocks in organic synthesis [79]. To picture the application profile of the studied catalysts, two members of the ene-yne class of compounds were investigated with catalysts $4 \mathbf{a}-\mathbf{e}$. Reactivity profiles for the metathesis of allyl 1,1-diphenylpropargyl ether (14) were established first (Scheme 6).

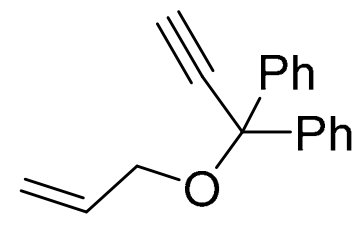

14

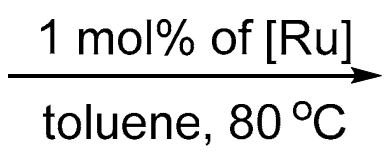

toluene, $80^{\circ} \mathrm{C}$

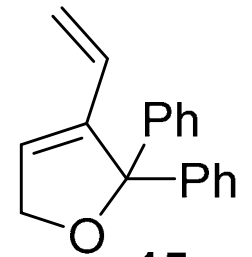

15

Scheme 6. Ene-yne reaction of allyl 1,1-diphenylpropargyl ether (14).

In the ene-yne cycloisomerisation of easy to react 14 [80] the most active were catalysts containing the smallest substituents $(\mathbf{4 a - c})$, while those with more bulky side chain groups $(\mathbf{4 d - e})$ showed diminished conversions (Figure 9). Nevertheless, all catalysts, but one, $\mathbf{4 d}$ contain a large cyclohexyl substituent in the ortho position of the aryl ring, provided the desired product with yields above $80 \%$ during the first $6 \mathrm{~h}$ of the reaction. Further extension of the reaction time to $24 \mathrm{~h}$ resulted in slight improvement of the results leading to essentially quantitative conversions (over $90 \%$ ) for $4 \mathbf{a}$ and $4 \mathbf{c}$ (Table 5). 


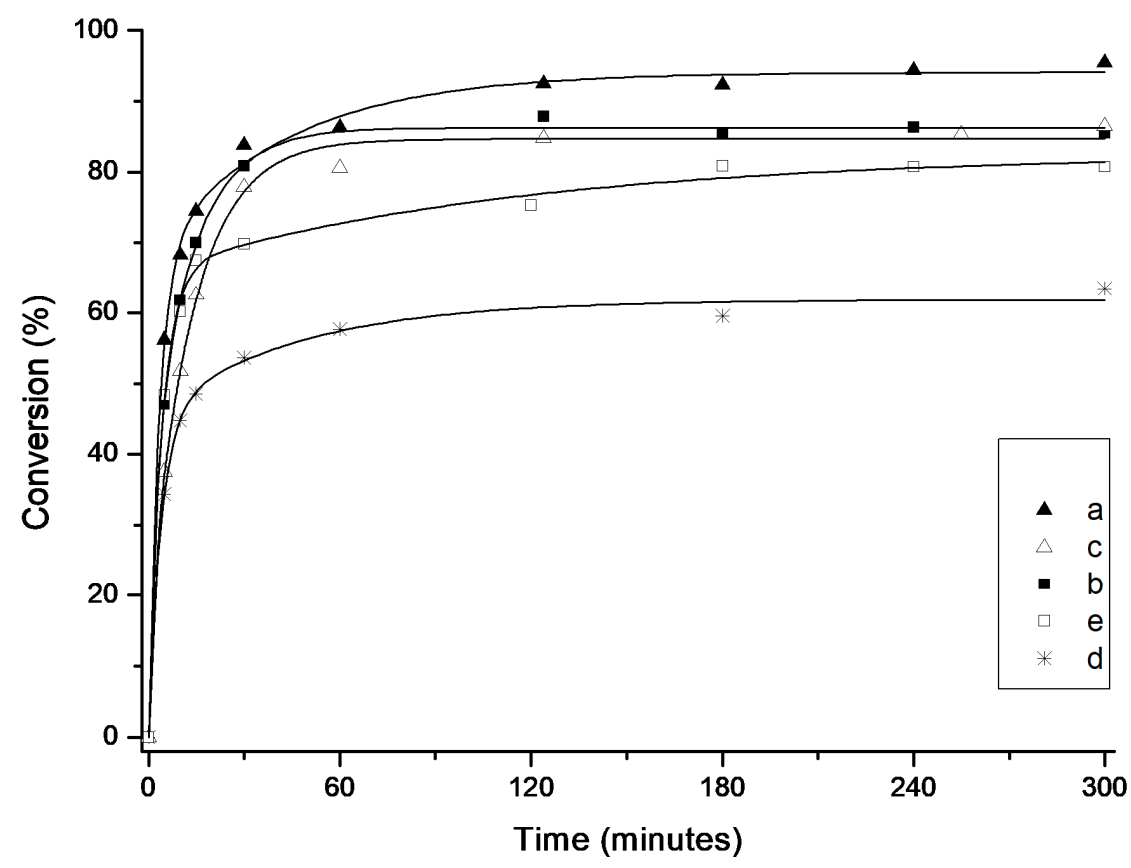

Figure 9. Time/conversion curves for the ene-yne reaction of allyl 1,1-diphenylpropargyl ether (14) with $1 \mathrm{~mol} \%$ of $4 \mathbf{a}-\mathbf{e}$ at $80^{\circ} \mathrm{C}$ (monitored by GC). Lines are visual aids only.

Table 5. Ene-yne reaction of allyl 1,1-diphenylpropargyl ether (14) with $1 \mathrm{~mol} \%$ of $4 a-\mathbf{e}$ at $80{ }^{\circ} \mathrm{C}$ (monitored by GC) after 6 and $24 \mathrm{~h}$.

\begin{tabular}{ccc}
\hline \multirow{2}{*}{ Catalyst } & \multicolumn{2}{c}{ Conversion (\%) } \\
\cline { 2 - 3 } & After $\mathbf{6} \mathbf{~ h}$ & After $\mathbf{2 4} \mathbf{~ h}$ \\
\hline $\mathbf{4 a}$ & 93 & 99 \\
$\mathbf{4 b}$ & 87 & 87 \\
$\mathbf{4 c}$ & 90 & 93 \\
$\mathbf{4 d}$ & 60 & 73 \\
$\mathbf{4 e}$ & 81 & 88 \\
\hline
\end{tabular}

Next, the more challenging cycloisomerisation substrate (1-(prop-1-en-2-yl-methoxy)prop-2-yne-1,1-diyl)dibenzene (16) [81-83] was utilised (Scheme 7). As for substrate 12, also in this case the loading of the catalysts was increased from 1 to $5 \mathrm{~mol} \%$ in order to obtain near-quantitative conversions.<smiles>C#CC(OCC(=C)C)(c1ccccc1)c1ccccc1</smiles>

Scheme 7. Ene-yne reaction of (1-(prop-1-en-2-yl-methoxy)prop-2-yne-1,1-diyl)dibenzene (16).

Indeed, most of the complexes used gave the expected product with a yield of $90-100 \%$ in less than 6 hours, with $4 \mathrm{~d}$ being the most active, and after extension of the reaction time to $24 \mathrm{~h} 100 \%$ of yield was reached (Table 6). The only exception was the complex $\mathbf{4 b}$ containing simple SIPr-ligand, which under these conditions gave only 25 and 41\% conversion, after 6 and 24 h respectively. 
Table 6. Ene-yne reaction of (1-(prop-1-en-2-yl-methoxy)prop-2-yne-1,1-diyl)dibenzene (16) with 5 $\mathrm{mol} \%$ of $4 \mathbf{a}-\mathbf{e}$ at $80^{\circ} \mathrm{C}$ (monitored by GC) after 6 and $24 \mathrm{~h}$.

\begin{tabular}{ccc}
\hline \multirow{2}{*}{ Catalyst } & \multicolumn{2}{c}{ Conversion (\%) } \\
\cline { 2 - 3 } & After $\mathbf{6} \mathbf{~ h}$ & After $\mathbf{2 4} \mathbf{~ h}$ \\
\hline $\mathbf{4 a}$ & 88 & 99 \\
$\mathbf{4 b}$ & 15 & 42 \\
$\mathbf{4 c}$ & 94 & 97 \\
$\mathbf{4 d}$ & 94 & 98 \\
$\mathbf{4 e}$ & 74 & 98 \\
\hline
\end{tabular}

\section{Experimental Section}

\subsection{General}

All reactions were carried out under argon flow in pre-dried glassware using Schlenk techniques. Reaction profiles performed in NMR tube were carried out in degassed $\mathrm{CD}_{2} \mathrm{Cl}_{2} \cdot \mathrm{CH}_{2} \mathrm{Cl}_{2}$ (Sigma-Aldrich Sp. z o.o., Poznan, Poland) was dried by distillation with $\mathrm{CaH}_{2}$ under argon and was stored under argon. THF, toluene, $n$-hexane and xylene were dried by distillation with $\mathrm{Na} / \mathrm{K}$ alloy. Flash chromatography was performed using Merck KGaA (Darmstadt, Germany) silica gel 60 (230-400 mesh). NMR spectra were recorded in $\mathrm{CDCl}_{3}$ or $\mathrm{CD}_{2} \mathrm{Cl}_{2}$ with Varian Mercury $400 \mathrm{MHz}$ and Varian VNMRS $500 \mathrm{MHz}$ spectrometers. MS (FD/FAB) was recorded with a GCT Premier spectrometer from Waters Corporation (Milford, MA, USA). MS (EI) spectra were recorded with an AMD 604 Intectra GmbH (Harpstedt, Germany) spectrometer. Other commercially available chemicals were used as received.

\subsection{Synthesis of Complexes}

Synthesis of 4a: Complex (2a) $(220 \mathrm{mg}, 0.232 \mathrm{mmol})$ was dissolved in toluene $(7 \mathrm{~mL})$, and 1-isopropoxy-4-nitro-2-(prop-1-en-1-yl)benzene (5) $(61.6 \mathrm{mg}, 0.278 \mathrm{mmol})$ was added. The mixture was stirred for $5 \mathrm{~min}, \mathrm{CuCl}(45.9 \mathrm{mg}, 0.474 \mathrm{mmol})$ was added, and the mixture was heated at $80{ }^{\circ} \mathrm{C}$ for $30 \mathrm{~min}$. The reaction mixture was cooled to room temperature and concentrated in vacuo. From this point, all manipulations were carried out in air with reagent grade solvents. The product was purified by silica gel chromatography $(\mathrm{AcOEt} / \mathrm{c}-\mathrm{hexane}=1: 4 v / v)$. The solvent was evaporated under vacuum, and the residue was dissolved in $\mathrm{CH}_{2} \mathrm{Cl}_{2}(2 \mathrm{~mL})$. $\mathrm{MeOH}(5 \mathrm{~mL})$ was added and $\mathrm{CH}_{2} \mathrm{Cl}_{2}$ was slowly removed under vacuum. The precipitated was filtered, washed with $\mathrm{MeOH}(5 \mathrm{~mL})$, and dried in vacuo to afford $4 \mathbf{a}$ as a green microcrystalline solid $(130 \mathrm{mg}, 83 \%) .{ }^{1} \mathrm{H}-\mathrm{NMR}\left(\mathrm{CD}_{2} \mathrm{Cl}_{2}, 500 \mathrm{MHz}\right.$ ): $\delta=16.42(\mathrm{~s}$, $1 \mathrm{H}), 8.46(\mathrm{dd}, J=9.1,2.5 \mathrm{~Hz}, 1 \mathrm{H}), 7.80(\mathrm{~d}, J=2.5 \mathrm{~Hz}, 1 \mathrm{H}), 7.10(\mathrm{~s}, 4 \mathrm{H}), 6.94(\mathrm{~d}, J=9.1 \mathrm{~Hz}, 1 \mathrm{H}), 5.01(\mathrm{sept}$, $J=6.1 \mathrm{~Hz}, 1 \mathrm{H}), 4.22(\mathrm{~s}, 4 \mathrm{H}), 2.46-2.48(\mathrm{~m}, 18 \mathrm{H}), 1.30(\mathrm{~d}, J=6.1 \mathrm{~Hz}, 6 \mathrm{H}),{ }^{13} \mathrm{C}-\mathrm{NMR}\left(125 \mathrm{MHz}, \mathrm{CD}_{2} \mathrm{Cl}_{2}\right)$ : $\delta=289.1,208.2,156.8,150.3,145.0,143.5,139.6,139.3,129.8,124.5,117.2,113.3,78.2,52.0,21.3,21.2$, 19.4; IR (KBr): $\tilde{\mathrm{v}}=2924,2850,1606,1521,1480,1262,1093,918,745 \mathrm{~cm}^{-1} ;$ FDMS m/z [M+1 671.1 .

Synthesis of $4 \mathbf{b}$ : Similar to the preparation of $4 \mathbf{a}, 5(150 \mathrm{mg}, 0.68 \mathrm{mmol})$ was added to the solution of complex $\mathbf{2 b}(690 \mathrm{mg}, 0.68 \mathrm{mmol})$ in toluene $(15 \mathrm{~mL})$. The mixture was stirred for $5 \mathrm{~min}$, and $\mathrm{CuCl}$ (135 mg, $1.36 \mathrm{mmol}$ ) was added. $4 \mathbf{b}$ was obtained as green microcrystalline solid (380 $\mathrm{mg}, 62 \%)$. ${ }^{1} \mathrm{H}-\mathrm{NMR}\left(500 \mathrm{MHz}, \mathrm{CD}_{2} \mathrm{Cl}_{2}\right): \delta=16.33(\mathrm{~s}, 1 \mathrm{H}), 8.38(\mathrm{dd}, J=9.0,2.7 \mathrm{~Hz}, 1 \mathrm{H}), 7.69(\mathrm{~d}, J=2.7 \mathrm{~Hz}, 1 \mathrm{H})$, $7.58(\mathrm{t}, J=7.7 \mathrm{~Hz}, 4 \mathrm{H}), 7.39(\mathrm{~d}, J=7.7 \mathrm{~Hz}, 4 \mathrm{H}), 6.90(\mathrm{~d}, J=9.0 \mathrm{~Hz}, 1 \mathrm{H}), 4.99(\mathrm{~m}, 1 \mathrm{H}), 4.20(\mathrm{~s}, 4 \mathrm{H}), 3.56$ $(\mathrm{m}, 4 \mathrm{H}), 1.40(\mathrm{~d}, J=6.1 \mathrm{~Hz}, 6 \mathrm{H}), 1.24(\mathrm{~d}, J=6.7 \mathrm{~Hz}, 12 \mathrm{H}) ;{ }^{13} \mathrm{C}-\mathrm{NMR}\left(125 \mathrm{MHz}, \mathrm{CD}_{2} \mathrm{Cl}_{2}\right): \delta=283.7$, 210.3, 156.6, 149.0, 143.6, 143.0, 136.2, 130.0, 124.4, 124.0, 116.7, 112.8, 77.7, 77.2, 77.0, 76.7, 54.5, 28.8, 26.5, 23.3, 21.7; IR (KBr): $\tilde{v}=3096,3069,2970,2951,2927,2868,1527,1341,1270,1095,914,742 \mathrm{~cm}^{-1}$; FDMS $m / z\left[\mathrm{M}^{+}\right] 755.10$.

Synthesis 4c: Complex 2c $(500 \mathrm{mg}, 0.571 \mathrm{mmol})$ was dissolved in toluene $(11 \mathrm{~mL})$, and 1-isopropoxy-4-nitro-2-(prop-1-en-1-yl)benzene (5) $(190 \mathrm{mg}, 0.856 \mathrm{mmol})$ was added. The mixture was stirred for $5 \mathrm{~min}, \mathrm{CuCl}(113 \mathrm{mg}, 1.14 \mathrm{mmol})$ was added, and the mixture was stirred at $70{ }^{\circ} \mathrm{C}$ for $40 \mathrm{~min}$. 
The reaction mixture was cooled to room temperature and concentrated in vacuo. From this point, all manipulations were carried out in air with reagent grade solvents. The product was purified by silica gel chromatography (AcOEt/c-hexane $=1: 5 v / v)$. The solvent was evaporated under vacuum, and the residue was dissolved in $\mathrm{CH}_{2} \mathrm{Cl}_{2}(2 \mathrm{~mL})$. $\mathrm{MeOH}(5 \mathrm{~mL})$ was added and $\mathrm{CH}_{2} \mathrm{Cl}_{2}$ was slowly removed under vacuum. The precipitated was filtered, washed with $\mathrm{MeOH}(5 \mathrm{~mL})$ and dried in vacuo to afford $4 \mathrm{c}$ as a brownish microcrystalline solid $(250 \mathrm{mg}, 63 \%) .{ }^{1} \mathrm{H}-\mathrm{NMR}\left(500 \mathrm{MHz}, \mathrm{CD}_{2} \mathrm{Cl}_{2}\right): \delta=16.57$ $(\mathrm{s}, 1 \mathrm{H}), 8.42(\mathrm{dd}, J=9.0,2.7 \mathrm{~Hz}, 1 \mathrm{H}), 7.92(\mathrm{~d}, J=2.5 \mathrm{~Hz}, 1 \mathrm{H}), 7.14(\mathrm{~s}, 4 \mathrm{H}), 6.89(\mathrm{~d}, J=9.0 \mathrm{~Hz}, 1 \mathrm{H}), 4.98$ $(\mathrm{m}, 1 \mathrm{H}), 2.48(\mathrm{~s}, 6 \mathrm{H}), 2.18(\mathrm{~s}, 12 \mathrm{H}), 1.97(\mathrm{~s}, 6 \mathrm{H}), 1.35(\mathrm{~d}, \mathrm{~J}=6.1 \mathrm{~Hz}, 6 \mathrm{H}) ;{ }^{13} \mathrm{C}-\mathrm{NMR}\left(125 \mathrm{MHz}, \mathrm{CD}_{2} \mathrm{Cl}_{2}\right)$ : $\delta=287.0,167.0,156.4,145.0,143.2,139.7,138.4,129.2,127.8,123.3,116.7,112.7,77.5,77.3,77.0,76.8$, 21.8, 21.1, 21.1, 19.1, 19.1; IR (KBr): $\tilde{\mathrm{v}}=3103,3084,2986,2969,2921,1604,1571,1520,1384,1337,1320$, $1095,746,660 \mathrm{~cm}^{-1} ;$ FDMS m/z [M+1 697.1 .

Synthesis of $4 \mathrm{~d}$ : Similar to the preparation of $4 \mathrm{c}, 5(86 \mathrm{mg}, 0.389 \mathrm{mmol})$ was added to the solution of complex 1d (250 mg, $0.243 \mathrm{mmol})$ in $\mathrm{CH}_{2} \mathrm{Cl}_{2}(15 \mathrm{~mL})$. The mixture was stirred for $5 \mathrm{~min}$, and $\mathrm{CuCl}$ (48 mg, $0.486 \mathrm{mmol}$ ) was added. 4d was obtained as green microcrystalline solid (180 mg, $87 \%)$. ${ }^{1} \mathrm{H}-\mathrm{NMR}\left(500 \mathrm{MHz}, \mathrm{CD}_{2} \mathrm{Cl}_{2}\right): \delta=16.04(\mathrm{~s}, 1 \mathrm{H}), 8.30(\mathrm{~d}, J=8.1 \mathrm{~Hz}, 2 \mathrm{H}), 8.23(\mathrm{dd}, J=9.0,2.7 \mathrm{~Hz}, 1 \mathrm{H})$, $8.08(\mathrm{~d} J=8.6,2 \mathrm{H}), 7.95(\mathrm{~d}, J=7.9 \mathrm{~Hz}, 2 \mathrm{H}), 7.68(\mathrm{~d}, J=8.6 \mathrm{~Hz}, 2 \mathrm{H}), 7.60(\mathrm{td}, J=6.9,1.0 \mathrm{~Hz}, 2 \mathrm{H}), 7.52(\mathrm{td}$, $J=6.9,1.0 \mathrm{~Hz}, 2 \mathrm{H}), 7.33(\mathrm{~d} J=2.5,1 \mathrm{H}), 6.71(\mathrm{~d}, J=9.0 \mathrm{~Hz}, 1 \mathrm{H}), 4.77(\mathrm{~m}, 1 \mathrm{H}), 4.48-4.34(\mathrm{~m}, 4 \mathrm{H}), 4.12$ $(\mathrm{q}, J=14.2,7.1 \mathrm{~Hz}, 1 \mathrm{H}), 3.11(\mathrm{~s}, 2 \mathrm{H}), 2.16(\mathrm{~s}, 1 \mathrm{H}), 2.04(\mathrm{~s}, 2 \mathrm{H}), 1.98-1.96(\mathrm{~m}, 12 \mathrm{H}), 1.74-1.55(\mathrm{~m}, 10 \mathrm{H})$, $1.48-1.37(\mathrm{~m}, 4 \mathrm{H}), 1.25(\mathrm{t}, J=7.1 \mathrm{~Hz}, 4 \mathrm{H}), 1.09(\mathrm{~d}, J=6.1 \mathrm{~Hz}, 2 \mathrm{H}), 1.01(\mathrm{~d}, J=6.1 \mathrm{~Hz}, 2 \mathrm{H}) ;{ }^{13} \mathrm{C}-\mathrm{NMR}$ $\left(125 \mathrm{MHz}, \mathrm{CD}_{2} \mathrm{Cl}_{2}\right): \delta=211.5,156.5,145.1,143.7,142.8,133.0,131.6,129.8,127.9,127.0,126.2,125.2$, $123.9,116.6,112.4,77.5,77.2,77.0,76.7,60.3,54.5,53.4,39.8,36.2,32.5,31.5,30.9,28.2,27.5,26.6,26.3$, 25.8, 21.1; IR (KBr): $\tilde{\mathrm{v}}=3067,2925,2849,1735,1523,1441,1340,1267,1091,914,818,747 \mathrm{~cm}^{-1}$; FDMS $m / z\left[\mathrm{M}^{+}\right]$851.2.

Synthesis of $4 \mathrm{e}$ : Similar to the preparation of $4 \mathrm{c}, 5(64.4 \mathrm{mg}, 0.291 \mathrm{mmol})$ was added to the solution of complex 1e $(200 \mathrm{mg}, 0.194 \mathrm{mmol})$ in $\mathrm{CH}_{2} \mathrm{Cl}_{2}(10 \mathrm{~mL})$. The mixture was stirred for $5 \mathrm{~min}$, and $\mathrm{CuCl}$ (38.4 mg, $0.388 \mathrm{mmol}$ ) was added. 4e was obtained as green microcrystalline solid (128 mg, $77 \%$ ). ${ }^{1} \mathrm{H}-\mathrm{NMR}\left(500 \mathrm{MHz}, \mathrm{CD}_{2} \mathrm{Cl}_{2}\right): \delta=16.39(\mathrm{~s}, 1 \mathrm{H}), 16.21(\mathrm{~s}, 1 \mathrm{H}), 8.21(\mathrm{dq}, J=8.9,2.5 \mathrm{~Hz}, 1 \mathrm{H}), 8.05(\mathrm{~d}, J$ $=8.9 \mathrm{~Hz}, 2 \mathrm{H}), 7.95(\mathrm{~s}, 1 \mathrm{H}), 7.86(\mathrm{dd} J=8.3,3.2,2 \mathrm{H}), 7.63(\mathrm{t}, J=8.9 \mathrm{~Hz}, 2 \mathrm{H}), 7.50(\mathrm{~d}, J=2.5 \mathrm{~Hz}, 1 \mathrm{H})$, 7.47-7.40 (m, 2H), $6.69(\mathrm{t}, J=8.3 \mathrm{~Hz}, 1 \mathrm{H}), 4.80-4.70(\mathrm{~m} \mathrm{1H}), 4.60(\mathrm{~s}, 1 \mathrm{H}), 4.47(\mathrm{t}, J=5.8 \mathrm{~Hz}, 2 \mathrm{H}), 3.65$ (quint, $J=13.1,6.7 \mathrm{~Hz}, 1 \mathrm{H}$ ), 3.22 (quint, $J=13.5,6.7 \mathrm{~Hz}, 1 \mathrm{H}$ ), 3.11 (quint, $J=13.5,6.8 \mathrm{~Hz}, 1 \mathrm{H}$ ), $1.44-1.36$ $(\mathrm{m}, 25 \mathrm{H}), 1.13(\mathrm{~d}, J=5.92 \mathrm{H}), 1.04(\mathrm{~d}, J=6.0 \mathrm{~Hz}, 2 \mathrm{H}), 0.93(\mathrm{~d}, J=6.0 \mathrm{~Hz}, 2 \mathrm{H}) ;{ }^{13} \mathrm{C}-\mathrm{NMR}(125 \mathrm{MHz}$, $\left.\mathrm{CD}_{2} \mathrm{Cl}_{2}\right): \delta=286.9,286.6,211.2,210.7,156.5,147.0,146.1,143.9,143.8,142.9,131.7,131.0,129.8,129.7$, $127.7,126.3,125.5,123.7,123.3,123.2,122.4,116.6,112.5,112.4,77.4,77.2,77.0,76.7,54.0,34.7,34.4,29.2$, 29.1, 25.8, 24.0, 23.5, 23.5, 23.3, 22.8, 22.6, 21.1, 21.0, 20.7; IR (KBr): $\tilde{\mathrm{v}}=3090,3058,2960,2870,1604,1525$, $1473,1340,1256,1092,845 \mathrm{~cm}^{-1} ;$ FDMS m/z $\left[\mathrm{M}^{+}\right]$855.3.

\section{Conclusions}

The family of nitro-complexes containing NHC ligands with different steric properties was synthesised, characterised and investigated in terms of activity. Analysis of the solid-state geometrical parameters manifested some interesting relationships. Intuitively, the most important difference in geometry was expressed by angle $\alpha$, representing visually how the $N$-aryl 'wings' of the NHC ligand are lowered towards the metal centre (Figure 4, Table 2). In the case of the SIPr-bearing $\mathbf{4 b}$ the $N$-aryl 'flaps' are slightly lowered compared to (S)IMes-decorated 4a,c. Interestingly, the naphthyl members of this series (4d-e) have the $N$-substituents even slightly more 'elevated' compared to their (S)IMes and SIPr counterparts (4a-b). This is in strong contrast to complex $\mathbf{4 f}$ where the NHC wings are visibly lowered, thus shielding much more the Ru centre. Interestingly, the latter complex, although very useful in cyclopolymerization of diynes, in model RCM reactions was found to be less reactive than

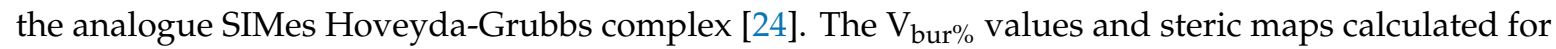
the studied complexes illustrated the same picture, rendering the naphthyl-containing complexes 
$\mathbf{4 d}-\mathbf{e}$ being the least crowded and $\mathbf{4 f}$ having the highest $\mathrm{V}_{\mathrm{bur} \%}$ value. The model reactions also sorted the tested complexes into two groups. While in the reaction of a simple model diene (6) all catalysts exhibited similarly high activity, in the case of a still rather straightforward cycloisomerisation of ene-yne 14, the less bulky NHC containing complexes $4 \mathbf{a}-\mathbf{c}$ were more active. At the same time, with more demanding sterically crowded substrates, a significant advantage of complexes with bulkier NHC ligands (4b, 4d-e) was evident. Importantly, complexes $4 \mathbf{d}-\mathbf{e}$ demonstrated high activity in formation of tetra-substituted C-C double bonds [78,84], the reaction which was traditionally Achilles' heel of the nitro-catalyst [42-45]. It is stressed that in all cases the studied model reactions were very clean and no side-products were observed.

Overall, the comparative study here suggests that the elaborated naphthyl-based catalysts (4d-e) may be better for challenging, sterically crowded substrates, while the 'easy' substrates can be transformed more readily in the presence of catalysts with standard NHC ligands (4a-b). Interestingly, catalysts $4 \mathrm{c}$ bearing $\mathrm{Me}_{2} \mathrm{IMes}$ ligand seemed the least utile.

These results show again [85] that different catalysts can be optimal for different applications, and that even small, sometimes incremental, variations can result in substantial changes in reactivity.

Supplementary Materials: The following are available online. Figure S1: Atomic Displacement Parameters (ADPs) and the labeling of atoms in $\mathbf{4 b}$ and $4 \mathbf{c}$; Figure S2: Atomic Displacement Parameters (ADPs) and the labeling of atoms in 4d; Figure S3: Atomic Displacement Parameters (ADPs) and the labeling of atoms in 4e for two molecules in asymmetric unit $\left(4 \mathbf{e}^{\prime}\right.$ and $\left.4 \mathbf{e}^{\prime \prime}\right)$; Figure S4: Overlay of molecules from the 4 a structure (black) with the $\mathbf{4 b}$ (magenta), $4 \mathrm{c}$ structure (blue), $4 \mathrm{~d}$ structure (green), $4 \mathrm{f}$ structure (grey), $4 \mathrm{e}^{\prime}$ structure (red) and $4 \mathrm{e}^{\prime \prime}$ (yellow) and 4g (grey; Figure S5: Atomic Displacement Parameters; Table S1: Experimental details for $4 \mathbf{b}-\mathbf{4 e}$ structures; Table S2: Experimental details for the CuClPCy3 measurement.

Author Contributions: Experiments and data analysis, M.P. and J.C.-J.; naphthyl ligands synthesis, R.D.; X-Ray

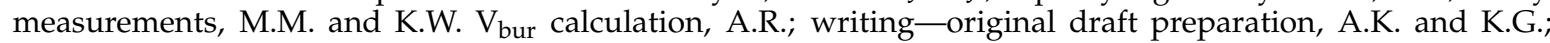
writing-review and editing, A.K., R.D. and K.G.; supervision, A.K. and K.G. All authors have read and agreed to the published version of the manuscript.

Funding: This research was funded by the OPUS project financed by the National Science Centre, Poland on the basis of a decision DEC-2014/15/B/ST5/02156.

Conflicts of Interest: The authors declare no conflict of interest. K.G. is an advisory board member of the Apeiron Synthesis company, the producer of catalyst $\mathbf{4 a - b}$.

\section{References}

1. Wanzlick, H.-W.; Schönherr, H.-J. Direct Synthesis of a Mercury Salt-Carbene Complex. Angew. Chem. Int. Ed. 1968, 7, 141-142. [CrossRef]

2. Öfele, K. 1,3-Dimethyl-4-imidazolinyliden-(2)-pentacarbonylchrom ein neuer übergangsmetall-carben-komplex. J. Organomet. Chem. 1968, 12, P42-P43. [CrossRef]

3. Arduengo, A.J.; Harlow, R.L.; Kline, M. A stable crystalline carbene. J. Am. Chem. Soc. 1991, 113, $361-363$. [CrossRef]

4. Gómez-Suárez, A.; Nelson, D.J.; Nolan, S.P. Quantifying and understanding the steric properties of N-heterocyclic carbenes. Chem. Commun. 2017, 53, 2650-2660. [CrossRef]

5. Cazin, C. (Ed.) N-Heterocyclic Carbenes in Transition Metal Catalysis and Organocatalysis; Springer: Dordrecht, The Netherlands, 2011; Volume 32, pp. 1-336.

6. Grubbs, R.H.; Wenzel, A.G.; O'Leary, D.J.; Khosravi, E. Handbook of Metathesis; Wiley-VCH: Weinheim, Germany, 2015.

7. Grela, K. Olefin Metathesis: Theory and Practice; John Wiley \& Sons, Inc.: Hoboken, NJ, USA, 2014.

8. Michrowska, A.; Grela, K. Quest for the ideal olefin metathesis catalyst. Pure Appl. Chem. 2008, 80, 31-43. [CrossRef]

9. Anderson, A.W.; Merckling, N.G. Polymeric Bicyclo-(2, 2, 1)-2-Heptene. U.S. Patent 2,721,189, 18 October 1955.

10. Banks, R.L.; Bailey, G.C. Olefin Disproportionation. A New Catalytic Process. Ind. Eng. Chem. Prod. Res. Dev. 1964, 3, 170-173. [CrossRef]

11. Natta, G.; Dall'Asta, G.; Mazzanti, G. Stereospecific Homopolymerization of Cyclopentene. Angew. Chem. Int. Ed. 1964, 3, 723-729. [CrossRef] 
12. Schrock, R.R.; Murdzek, J.S.; Bazan, G.C.; Robbins, J.; Dimare, M.; O’Regan, M. Synthesis of molybdenum imido alkylidene complexes and some reactions involving acyclic olefins. J. Am. Chem. Soc. 1990, 112, 3875-3886. [CrossRef]

13. Schwab, P.; Grubbs, R.H.; Ziller, J.W. Synthesis and Applications of RuCl2(CHR')(PR3)2: The Influence of the Alkylidene Moiety on Metathesis Activity. J. Am. Chem. Soc. 1996, 118, 100-110. [CrossRef]

14. Ackermann, L.; Fürstner, A.; Weskamp, T.; Kohl, F.J.; Herrmann, W.A. Ruthenium carbene complexes with imidazolin-2-ylidene ligands allow the formation of tetrasubstituted cycloalkenes by RCM. Tetrahedron Lett. 1999, 40, 4787-4790. [CrossRef]

15. Huang, J.; Stevens, E.D.; Nolan, S.P.; Petersen, J.L. Olefin Metathesis-Active Ruthenium Complexes Bearing a Nucleophilic Carbene Ligand. J. Am. Chem. Soc. 1999, 121, 2674-2678. [CrossRef]

16. Scholl, M.; Trnka, T.M.; Morgan, J.P.; Grubbs, R.H. Increased ring closing metathesis activity of ruthenium-based olefin metathesis catalysts coordinated with imidazolin-2-ylidene ligands. Tetrahedron Lett. 1999, 40, 2247-2250. [CrossRef]

17. Available online: https://pmc.umicore.com/en/products/umicore-grubbs-catalyst-m2a-c848/ (accessed on 15 April 2020).

18. Scholl, M.; Ding, S.; Lee, C.W.; Grubbs, R.H. Synthesis and activity of a new generation of ruthenium-based olefin metathesis catalysts coordinated with 1,3-dimesityl-4,5-dihydroimidazol-2-ylidene ligands. Org. Lett. 1999, 1, 953-956. [CrossRef] [PubMed]

19. Available online: https://catalysts.evonik.com/product/catalysts/downloads/homogeneous_catalysts_evonik. pdf (accessed on 15 April 2020).

20. Available online: https://pmc.umicore.com/en/products/umicore-grubbs-catalyst-m2/ (accessed on 15 April 2020).

21. Available online: https:/www.sigmaaldrich.com/catalog/product/sial/901755?lang=pl\&region=PL (accessed on 15 April 2020).

22. Available online: https://www.strem.com/catalog/v/44-0758/59/ruthenium_502964-52-5 (accessed on 15 April 2020).

23. Available online: https://www.strem.com/catalog/v/44-0770/59/ruthenium_928795-51-1 (accessed on 15 April 2020).

24. Yang, L.; Mayr, M.; Wurst, K.; Buchmeiser, M.R. Novel metathesis catalysts based on ruthenium 1,3-dimesityl-3,4,5,6-tetrahydropyrimidin-2-ylidenes: Synthesis, structure, immobilization, and catalytic activity. Chem. Eur. J. 2004, 10, 5761-5770. [CrossRef]

25. Despagnet-Ayoub, E.; Grubbs, R.H. A ruthenium olefin metathesis catalyst with a four-membered N-heterocyclic carbene ligand. Organometallics 2005, 24, 338. [CrossRef]

26. Fürstner, A.; Ackermann, L.; Gabor, B.; Goddard, R.; Lehmann, C.W.; Mynott, R.; Stelzer, F.; Thiel, O.R. Comparative investigation of ruthenium-based metathesis catalysts bearing N-heterocyclic carbene (NHC) ligands. Chem.-A Eur. J. 2001, 7, 3236-3253. [CrossRef]

27. Dinger, M.B.; Nieczypor, P.; Mol, J.C. Adamantyl-Substituted N-Heterocyclic Carbene Ligands in Second-Generation Grubbs-Type Metathesis Catalysts. Organometallics 2003, 22, 5291. [CrossRef]

28. Yun, J.; Marinez, E.R.; Grubbs, R.H. A new ruthenium-based olefin metathesis catalyst coordinated with 1, 3-dimesityl-1, 4, 5, 6-tetrahydropyrimidin-2-ylidene: synthesis, X-ray structure, and reactivity. Organometallics 2004, 23, 4172. [CrossRef]

29. Vehlow, K.; Maechling, S.; Blechert, S. Ruthenium metathesis catalysts with saturated unsymmetrical N-heterocyclic carbene ligands. Organometallics 2006, 25, 25. [CrossRef]

30. Ledoux, N.; Allaert, B.; Pattyn, S.; Vander Mierde, H.; Vercaemst, C.; Verpoort, F. N,N'-Dialkyl- and $\mathrm{N}$-Alkyl-N-mesityl-Substituted $\mathrm{N}$-Heterocyclic Carbenes as Ligands in Grubbs Catalysts. Chem. Eur. J. 2006, 12, 4654. [CrossRef]

31. Tornatzky, J.; Kannenberg, A.; Blechert, S. New catalysts with unsymmetrical N-heterocyclic carbene ligands. Dalton Trans. 2012, 41, 8215. [CrossRef] [PubMed]

32. Hamad, F.B.; Sun, T.; Xiao, S.; Verpoort, F. Olefin metathesis ruthenium catalysts bearing unsymmetrical heterocylic carbenes. Coord. Chem. Rev. 2013, 257, 2274-2292. [CrossRef]

33. Paradiso, V.; Costabile, C.; Grisi, F. Ruthenium-based olefin metathesis catalysts with monodentate unsymmetrical NHC ligands. Beilstein J. Org. Chem. 2018, 14, 3122-3149. [CrossRef] [PubMed]

34. Dinger, M.B.; Mol, J.C. High turnover numbers with ruthenium-based metathesis catalysts. Adv. Synth. Catal. 2002, 344, 671-677. [CrossRef]

35. Banti, D.; Mol, J.C. Degradation of the ruthenium-based metathesis catalyst $[\mathrm{RuCl} 2(\mathrm{CHPh})(\mathrm{H} 2 \mathrm{IPr})(\mathrm{PCy} 3)]$ with primary alcohols. J. Organomet. Chem. 2004, 689, 3113. [CrossRef] 
36. Clavier, H.; Urbina-Blanco, C.A.; Nolan, S.P. Indenylidene Ruthenium Complex Bearing a Sterically Demanding NHC Ligand: An Efficient Catalyst for Olefin Metathesis at Room Temperature. Organometallics 2009, 28, 2848-2854. [CrossRef]

37. Gallenkamp, D.; Fürstner, A. Stereoselective Synthesis ofE,Z-Configured 1,3-Dienes by Ring-Closing Metathesis. Application to the Total Synthesis of Lactimidomycin. J. Am. Chem. Soc. 2011, 133, 9232-9235. [CrossRef]

38. Bieniek, M.; Bujok, R.; Stepowska, H.; Jacobi, A.; Hagenkötter, R.; Arlt, D.; Jarzembska, K.N.; Makal, A.; Woźniak, K.; Grela, K. New air-stable ruthenium olefin metathesis precatalysts derived from bisphenol S. J. Organomet. Chem. 2006, 691, 5289-5297. [CrossRef]

39. Arduengo, A.J.; Davidson, F.; Dias, H.V.R.; Goerlich, J.R.; Khasnis, D.; Marshall, W.J.; Prakasha, T.K. An Air Stable Carbene and Mixed Carbene “Dimers. " J. Am. Chem. Soc. 1997, 119, 12742-12749. [CrossRef]

40. Kadyrov, R.; Rosiak, A.; Tarabocchia, J.; Szadkowska, A.; Bieniek, M.; Grela, K. New concepts in designing ruthenium-based second generation olefin metathesis catalysts and their application. In Catalysis of Organic Reactions; CRC Press: Boca Raton, FL, USA, 2008; pp. 217-222.

41. Ginzburg, Y.; Lemcoff, N. Hoveyda-Type Olefin Metathesis Complexes. In Olefin Metathesis; Wiley: Hoboken, NJ, USA, 2014; pp. 437-451.

42. Grela, K.; Harutyunyan, S.; Michrowska, A. A Highly Efficient Ruthenium Catalyst for Metathesis Reactions. Angew. Chem. Int. Ed. 2002, 41, 4038-4040. [CrossRef]

43. Michrowska, A.; Bujok, R.; Harutyunyan, S.; Sashuk, V.; Dolgonos, G.; Grela, K.; Dolgonos, G.A. Nitro-Substituted Hoveyda-Grubbs Ruthenium Carbenes: Enhancement of Catalyst Activity through Electronic Activation. J. Am. Chem. Soc. 2004, 126, 9318-9325. [CrossRef] [PubMed]

44. Grela, K. Ruthenium Complexes as (Pre)catalysts for Metathesis Reactions. U.S. Patent 6,867,303, 15 March 2005.

45. Bieniek, M.; Michrowska, A.; Gułajski, Ł.; Grela, K. A Practical Larger Scale Preparation of Second-Generation Hoveyda-Type Catalysts. Organometallics 2007, 26, 1096-1099. [CrossRef]

46. Zhan, Z.-Y.J. Recyclable Ruthenium Catalysts for Metathesis Reactions. U.S. Patent 7,632,772, 15 December 2009.

47. Lindner, F.; Friedrich, S.; Hahn, F. Total Synthesis of Complex Biosynthetic Late-Stage Intermediates and Bioconversion by a Tailoring Enzyme from Jerangolid Biosynthesis. J. Org. Chem. 2018, 83, 14091-14101. [CrossRef] [PubMed]

48. Stellfeld, T.; Bhatt, U.; Kalesse, M. Synthesis of the A,B,C-Ring System of Hexacyclinic Acid. Org. Lett. 2004, 6, 3889-3892. [CrossRef] [PubMed]

49. Shu, C.; Zeng, X.; Hao, M.-H.; Wei, X.; Yee, N.K.; Busacca, C.A.; Han, Z.; Farina, V.; Senanayake, C.H. RCM Macrocyclization Made Practical: An Efficient Synthesis of HCV Protease Inhibitor BILN. Org. Lett. 2008, 10, 1303-1306. [CrossRef] [PubMed]

50. Farina, V.; Shu, C.; Zeng, X.; Wei, X.; Han, Z.; Yee, N.K.; Senanayake, C.H. Second-Generation Process for the HCV Protease Inhibitor BILN 2061: A Greener Approach to Ru-Catalyzed Ring-Closing Metathesist. Org. Process Res. Dev. 2009, 13, 250-254. [CrossRef]

51. Chen, Q.-Y.; Chaturvedi, P.R.; Luesch, H. Process development and scale-up total synthesis of largazole, a potent class i histone deacetylase inhibitor. Org. Process Res. Dev. 2018, 22, 190-199. [CrossRef]

52. Breen, C.P.; Parrish, C.; Shangguan, N.; Majumdar, S.; Murnen, H.; Jamison, T.F.; Bio, M.M. A scalable membrane pervaporation approach for continuous flow olefin metathesis. Org. Process Res. Dev. 2020. [CrossRef]

53. Tracz, A.; Matczak, M.; Urbaniak, K.; Skowerski, K. Nitro-grela-type complexes containing iodides-robust and selective catalysts for olefin metathesis under challenging conditions. Beilstein J. Org. Chem. 2015, 11, 1823-1832. [CrossRef]

54. Marx, V.M.; Sullivan, A.H.; Melaimi, M.; Virgil, S.C.; Keitz, B.K.; Weinberger, D.S.; Bertrand, G.; Grubbs, R.H. Cyclic alkyl amino carbene (caac) ruthenium complexes as remarkably active catalysts for ethenolysis. Angew. Chem. Int. Ed. 2015, 54, 1919-1923. [CrossRef]

55. Gawin, R.; Tracz, A.; Chwalba, M.; Kozakiewicz, A.; Trzaskowski, B.; Skowerski, K. Cyclic Alkyl Amino Ruthenium Complexes-Efficient Catalysts for Macrocyclization and Acrylonitrile Cross Metathesis. ACS Catal. 2017, 7, 5443-5449. [CrossRef]

56. Schmid, T.E.; Dumas, A.; Colombel-Rouen, S.; Crévisy, C.; Baslé, O.; Mauduit, M. From environmentally friendly reusable ionic-tagged ruthenium-based complexes to industrially relevant homogeneous catalysts: Toward a sustainable olefin metathesis. Synlett 2017, 28, 773-798. 
57. Bieniek, M.; Bujok, R.; Milewski, M.; Arlt, D.; Kajetanowicz, A.; Grela, K. Making the family portrait complete: Synthesis of electron withdrawing group activated Hoveyda-Grubbs catalysts bearing sulfone and ketone functionalities. J. Organomet. Chem. 2020, 918, 121276. [CrossRef]

58. Bieniek, M.; Samojłowicz, C.; Sashuk, V.; Bujok, R.; Śledź, P.; Lugan, N.; Lavigne, G.; Arlt, D.; Grela, K. Rational design and evaluation of upgraded Grubbs/Hoveyda olefin metathesis catalysts: Polyfunctional benzylidene ethers on the test bench. Organometallics 2011, 30, 4144-4158. [CrossRef]

59. Eivgi, O.; Sutar, R.L.; Reany, O.; Lemcoff, N.G. Bichromatic photosynthesis of coumarins by UV filter-enabled olefin metathesis. Adv. Synth. Catal. 2017, 359, 2352-2357. [CrossRef]

60. Ivry, E.; Frenklah, A.; Ginzburg, Y.; Levin, E.; Goldberg, I.; Kozuch, S.; Lemcoff, N.G.; Tzur, E. Light- and thermal-activated olefin metathesis of hindered substrates. Organometallics 2018, 37, 176-181. [CrossRef]

61. Tzur, E.; Szadkowska, A.; Ben-Asuly , A.; Makal, A.; Goldberg, I.; Woźniak, K.; Grela , K.; Lemcoff, N.G. Studies on electronic effects in $\mathrm{O}_{-}, \mathrm{N}$ - and $\mathrm{S}$-chelated ruthenium olefin-metathesis catalysts. Chem.-A Eur. J. 2010, 16, 8726-8737. [CrossRef]

62. Żukowska, K.; Szadkowska, A.; Pazio, A.E.; Woźniak, K.; Grela, K. Thermal switchability of N-chelating Hoveyda-type catalyst containing a secondary amine ligand. Organometallics 2012, 31, 462-469. [CrossRef]

63. Gawin, A.; Pump, E.; Slugovc, C.; Kajetanowicz, A.; Grela, K. Ruthenium amide complexes-Synthesis and catalytic activity in olefin metathesis and in ring-opening polymerisation. Eur. J. Inorg. Chem. 2018, 2018, 1766-1774. [CrossRef]

64. Monsaert, S.; Lozano Vila, A.; Drozdzak, R.; Van Der Voort, P.; Verpoort, F. Latent olefin metathesis catalysts. Chem. Soc. Rev. 2009, 38, 3360-3372. [CrossRef]

65. Eivgi, O.; Lemcoff, N.G. Turning the light on: Recent developments in photoinduced olefin metathesis. Synthesis 2018, 50, 49-63.

66. Luan, X.; Mariz, R.; Gatti, M.; Costabile, C.; Poater, A.; Cavallo, L.; Linden, A.; Dorta, R. Identification and characterization of a new family of catalytically highly active imidazolin-2-ylidenes. J. Am. Chem. Soc. 2008, 130, 6848-6858. [CrossRef] [PubMed]

67. Vieille-Petit, L.; Luan, X.; Mariz, R.; Blumentritt, S.; Linden, A.; Dorta, R. A new class of stable, saturated $N$-heterocyclic carbenes with $N$-naphthyl substituents: Synthesis, dynamic behavior, and catalytic potential. Eur. J. Inorg. Chem. 2009, 2009, 1861-1870. [CrossRef]

68. Vieille-Petit, L.; Clavier, H.; Linden, A.; Blumentritt, S.; Nolan, S.P.; Dorta, R. Ruthenium olefin metathesis catalysts with $N$-heterocyclic carbene ligands bearing $N$-naphthyl side chains. Organometallics 2010, 29, 775-788. [CrossRef]

69. Winter, P.; Hiller, W.; Christmann, M. Access to Skipped Polyene Macrolides through Ring-Closing Metathesis: Total Synthesis of the RNA Polymerase Inhibitor Ripostatin B. Angew. Chem. Int. Ed. 2012, 51, 3396-3400. [CrossRef]

70. Ritter, T.; Hejl, A.; Wenzel, A.G.; Funk, T.W.; Grubbs, R.H. A standard system of characterization for olefin metathesis catalysts. Organometallics 2006, 25, 5740-5745. [CrossRef]

71. Garber, S.B.; Kingsbury, J.S.; Gray, B.L.; Hoveyda, A.H. Efficient and Recyclable Monomeric and Dendritic Ru-Based Metathesis Catalysts. J. Am. Chem. Soc. 2000, 122, 8168-8179. [CrossRef]

72. Rivard, M.; Blechert, S. Effective and Inexpensive Acrylonitrile Cross-Metathesis: Utilisation of Grubbs II Precatalyst in the Presence of Copper(I) Chloride. Eur. J. Org. Chem. 2003, 2003, 2225-2228. [CrossRef]

73. Vieille-Petit, L.; Luan, X.; Gatti, M.; Blumentritt, S.; Linden, A.; Clavier, H.; Nolan, S.P.; Dorta, R. Improving Grubbs' II type ruthenium catalysts by appropriately modifying the N-heterocyclic carbene ligand. Chem. Commun. 2009, 25, 3783-3785. [CrossRef]

74. Samojłowicz, C.; Bieniek, M.; Grela, K. Ruthenium-based olefin metathesis catalysts bearing N-heterocyclic carbene ligands. Chem. Rev. 2009, 109, 3708-3742. [CrossRef]

75. Barbasiewicz, M.; Szadkowska, A.; Makal, A.; Jarzembska, K.N.; Grela, K.; Woźniak, K. Is the Hoveyda-Grubbs Complex a Vinylogous Fischer-Type Carbene? Aromaticity-Controlled Activity of Ruthenium Metathesis Catalysts. Chem.-A Eur. J. 2008, 14, 9330-9337. [CrossRef] [PubMed]

76. Falivene, L.; Credendino, R.; Poater, A.; Petta, A.; Serra, L.; Oliva, R.; Scarano, V.; Cavallo, L. SambVca A Web Tool for Analyzing Catalytic Pockets with Topographic Steric Maps. Organometallics 2016, 35, 2286-2293. [CrossRef]

77. Chatterjee, A.K.; Choi, T.-L.; Sanders, D.P.; Grubbs, R.H. A general model for selectivity in olefin cross metathesis. J. Am. Chem. Soc. 2003, 125, 11360-11370. [CrossRef] [PubMed] 
78. Mukherjee, N.; Planer, S.; Grela, K. Formation of tetrasubstituted C-C double bonds via olefin metathesis: Challenges, catalysts, and applications in natural product synthesis. Org. Chem. Front. 2018, 5, 494-516. [CrossRef]

79. Diver, S.T.; Griffiths, J.R. Ene-yne metathesis. In Olefin Metathesis: Theory and Practice; Grela, K., Ed.; John Wiley \& Sons: Hoboken, NJ, USA, 2014; pp. 153-185.

80. Grotevendt, A.G.D.; Lummiss, J.A.M.; Mastronardi, M.L.; Fogg, D.E. Ethylene-Promoted versus Ethylene-Free Enyne Metathesis. J. Am. Chem. Soc. 2011, 133, 15918-15921. [CrossRef]

81. Schmid, T.E.; Bantreil, X.; Citadelle, C.A.; Slawin, A.; Cazin, C.S.J. Phosphites as ligands in ruthenium-benzylidene catalysts for olefin metathesis. Chem. Commun. 2011, 47, 7060-7062. [CrossRef]

82. Guidone, S.; Blondiaux, E.; Samojłowicz, C.; Gułajski, Ł.; Kędziorek, M.; Malinska, M.; Pazio, A.; Wozniak, K.; Grela, K.; Doppiu, A.; et al. Catalytic and Structural Studies of Hoveyda-Grubbs Type Pre-Catalysts Bearing Modified Ether Ligands. Adv. Synth. Catal. 2012, 354, 2734-2742. [CrossRef]

83. Broggi, J.; Urbina-Blanco, C.A.; Clavier, H.; Leitgeb, A.; Slugovc, C.; Slawin, A.; Nolan, S.P. The Influence of Phosphane Ligands on the Versatility of Ruthenium-Indenylidene Complexes in Metathesis. Chem.-A Eur. J. 2010, 16, 9215-9225. [CrossRef]

84. Lecourt, C.; Dhambri, S.; Allievi, L.; Sanogo, Y.; Zeghbib, N.; Ben Othman, R.; Lannou, M.-I.; Sorin, G.; Ardisson, J. Natural products and ring-closing metathesis: synthesis of sterically congested olefins. Nat. Prod. Rep. 2018, 35, 105-124. [CrossRef]

85. Bieniek, M.; Michrowska, A.; Usanov, D.L.; Grela, K. In an attempt to provide a user's guide to the galaxy of benzylidene, alkoxybenzylidene, and indenylidene ruthenium olefin metathesiss catalysts. Chem. A Eur. J. 2008, 14, 806-818. [CrossRef]

Sample Availability: Samples of the compounds are not available from the authors.

(C) 2020 by the authors. Licensee MDPI, Basel, Switzerland. This article is an open access article distributed under the terms and conditions of the Creative Commons Attribution (CC BY) license (http://creativecommons.org/licenses/by/4.0/). 